\title{
Pathogenesis and management of postprandial hyperglycemia: role of incretin-based therapies
}

This article was published in the following Dove Press journal:

International Journal of General Medicine

3 December 2013

Number of times this article has been viewed

\section{John Gerich}

Department of Medicine, Endocrine/ Metabolism Division, University of Rochester School of Medicine, Rochester, NY, USA
Correspondence: John Gerich 403 Woodcrest Road, Wayne, PA 19087, USA

$\mathrm{Tel}+\mathrm{I} 5857522860$

Fax + I 6102939588

Email johngerich@compuserve.com
Abstract: Postprandial plasma glucose concentrations are an important contributor to glycemic control. There is evidence suggesting that postprandial hyperglycemia may be an independent risk factor for cardiovascular disease. Glucagon-like peptide-1 (GLP-1) receptor agonists and dipeptidyl peptidase-4 (DPP-4) inhibitors are antidiabetic agents that predominantly reduce postprandial plasma glucose levels. DPP-4 inhibitors are associated with fewer gastrointestinal side effects than GLP-1 receptor agonists and are administered orally, unlike GLP-1 analogs, which are administered as subcutaneous injections. GLP-1 receptor agonists are somewhat more effective than DPP-4 inhibitors in reducing postprandial plasma glucose and are usually associated with significant weight loss. For these reasons, GLP-1 receptor agonists are generally preferred over DPP-4 inhibitors as part of combination treatment regimens in patients with glycated hemoglobin levels above $8.0 \%$. This article reviews the pathogenesis of postprandial hyperglycemia, the mechanisms by which GLP-1 receptor agonists and DPP-4 inhibitors reduce postprandial plasma glucose concentrations, and the results of recent clinical trials (ie, published 2008 to October 2012) that evaluated the effects of these agents on postprandial plasma glucose levels when evaluated as monotherapy compared with placebo or as add-on therapy to metformin, a sulfonylurea, or insulin. Findings from recent clinical studies suggest that both GLP-1 receptor agonists and DPP-4 inhibitors could become valuable treatment options for optimizing glycemic control in patients unable to achieve glycated hemoglobin goals on basal insulin, with the added benefits of weight loss and a low risk of hypoglycemia.

Keywords: postprandial hyperglycemia, glucagon-like peptide-1, dipeptidyl peptidase-4, type 2 diabetes mellitus

\section{Introduction}

Type 2 diabetes is a chronic, progressive disease in which hyperglycemia occurs due to an imbalance between the body's need for insulin and its ability to produce it. The progressive nature of the disease results from a continuing deterioration in pancreatic $\beta$-cell function and development of hyperglycemia. ${ }^{1-3}$ The first step in the deterioration of glucose homeostasis is the loss of postprandial glycemic control, which is followed by a progression to morning hyperglycemia and eventually to sustained nocturnal hyperglycemia. ${ }^{4-6}$ Impaired glucose tolerance is considered a prediabetic stage, and it may occur years before elevated fasting plasma glucose (FPG) levels are observed. ${ }^{7}$ It is defined as 2-hour postprandial plasma glucose (PPG) levels between 140 and $199 \mathrm{mg} / \mathrm{dL}$ following a $75 \mathrm{~g}$ oral glucose tolerance test. ${ }^{6,8}$ Postprandial hyperglycemia can be the rate-limiting factor for achieving optimal glycemic control. ${ }^{9}$ 
There is also evidence suggesting that postprandial hyperglycemia may be an independent risk factor for cardiovascular disease, stroke, retinopathy, renal failure, and neurologic complications in both diabetic and nondiabetic individuals. ${ }^{410-13}$ One of the proposed mechanisms of diabetic vascular disease is the observed increase in oxidative stress that occurs following consumption of meals that produce a high level of glycemia. ${ }^{14,15}$ This oxidative stress has been shown to induce endothelial dysfunction and increase inflammation, vasoconstriction, and carotid intima-media thickness. ${ }^{7,13,16}$

PPG control is important not only for regulating glycemia, but also because reducing postprandial hyperglycemia may mitigate cardiovascular risks. To achieve optimal glycemic control, the consensus statement of the American Diabetes Association (ADA) and the European Association for the Study of Diabetes (EASD) recommends a patient-centered approach to incorporate individual factors such as lifestyle, cost, motivation, and need to lose weight. ${ }^{17}$ Further, the most recent guidelines from the International Diabetes Federation recognize the importance of PPG control in mitigating cardiovascular risks and include strategies for cardiovascular risk reduction as a major focus of therapy. ${ }^{18}$

Two noninsulin classes of drugs that have shown significant clinical benefits by predominantly reducing PPG excursions and lowering glycated hemoglobin $\left(\mathrm{HbA}_{1 \mathrm{c}}\right)$ are glucagon-like peptide-1 (GLP-1) derivatives (eg, the US Food and Drug Administration [FDA]-approved drugs liraglutide, exenatide, and exenatide long-acting release [LAR]; and the investigational drugs albiglutide and lixisenatide) and dipeptidyl peptidase-4 (DPP-4) inhibitors (eg, the FDA-approved sitagliptin, saxagliptin, and linagliptin). ${ }^{10,19}$ The purpose of this paper is to review the pathogenesis of postprandial hyperglycemia, the mechanisms by which GLP-1 receptor agonists and DPP-4 inhibitors reduce PPG concentrations, and the results of recent clinical trials that have evaluated the effects of GLP-1 receptor agonists and DPP-4 inhibitors (the newest class to become available) on PPG levels, specifically as monotherapy versus placebo or as add-on therapy to metformin, a sulfonylurea, or insulin.

\section{Pathogenesis of postprandial hyperglycemia}

In nondiabetic individuals, pancreatic $\beta$-cells increase the release of insulin in response to food consumption and release a relatively constant level of insulin during the fasting state. After food ingestion, an increase in plasma glucose levels and a release of insulin inhibit glucagon secretion; together, these suppress glucagon release into the circulation by the liver and kidneys and promote glucose uptake in various tissues.

In people with postprandial hyperglycemia, early insulin release after food ingestion is decreased and there is less reduction in glucagon secretion, resulting in inappropriate glucose production in the liver and kidneys and inefficient glucose uptake, and consequently, increased PPG levels..$^{20,21}$ The overall amount of ingested glucose absorbed by the body does not change. ${ }^{20,22}$ Mass action effects of hyperglycemia normalize the absolute amount of PPG taken up by tissues. However, there is decreased tissue glucose clearance and glucose oxidation, with increased nonoxidative glycolysis, glycogen cycling, and glucose uptake in alternative tissues throughout the body. ${ }^{20,23}$ The net result is that more glucose (endogenous + ingested) enters the circulation at a faster rate than the body can remove it, resulting in prolonged elevations of plasma glucose..$^{20-22}$

Several studies demonstrate that management of PPG is important for achieving glycemic control. Monnier et al assessed the relative importance of postprandial and fasting hyperglycemia on overall glycemic control in 290 patients (139 male/151 female; mean age \pm standard deviation $60 \pm 1$ years) and found that postprandial hyperglycemia was responsible for approximately $70 \%$ of daylong hyperglycemia in patients with $\mathrm{HbA}_{1 \mathrm{c}}$ levels below $7.3 \%$, compared with approximately $40 \%$ in patients with $\mathrm{HbA}_{1 \mathrm{c}}$ levels of $9.3 \%$ or higher. ${ }^{24}$ Similarly, Woerle et al found that in 164 patients ( 90 male/74 female; mean age $62 \pm 1$ years), over $80 \%$ of $\mathrm{HbA}_{1 \mathrm{c}}$ was due to postprandial hyperglycemia in patients with $\mathrm{HbA}_{1 \mathrm{c}}$ levels below $6.2 \%$, whereas only about $40 \%$ of $\mathrm{HbA}_{1 \mathrm{c}}$ was due to postprandial hyperglycemia in patients with $\mathrm{HbA}_{1 \mathrm{c}}$ levels $>8.9 \% .{ }^{9}$ In an analysis of 1,699 patients ( $58 \%$ male $/ 42 \%$ female; mean age $59 \pm 9$ years) from six clinical trials in which patients with $\mathrm{HbA}_{1 \mathrm{c}}$ levels $>7.0 \%$ taking oral therapy received treatment intensification, Riddle et al found that the effect of targeting PPG became more important in patients who were unable to achieve glycemic control after basal insulin therapy. ${ }^{25}$ In this study, the relative contribution of $\mathrm{FPG}$ to $\mathrm{HbA}_{1 \mathrm{c}}$ was in the range of $76 \%-80 \%$ at baseline but decreased to $31.5 \%-41 \%$ after $24-28$ weeks of treatment with basal insulin therapy.

In the early stages of prediabetes and diabetes, the deleterious effects of an imbalance between impaired insulin secretion and insulin resistance are more apparent in the postprandial state than in the fasting state (Figure 1). ${ }^{4} \mathrm{PPG}$ levels increase earlier and faster than FPG levels because more insulin is needed after meals than in the fasting state in 


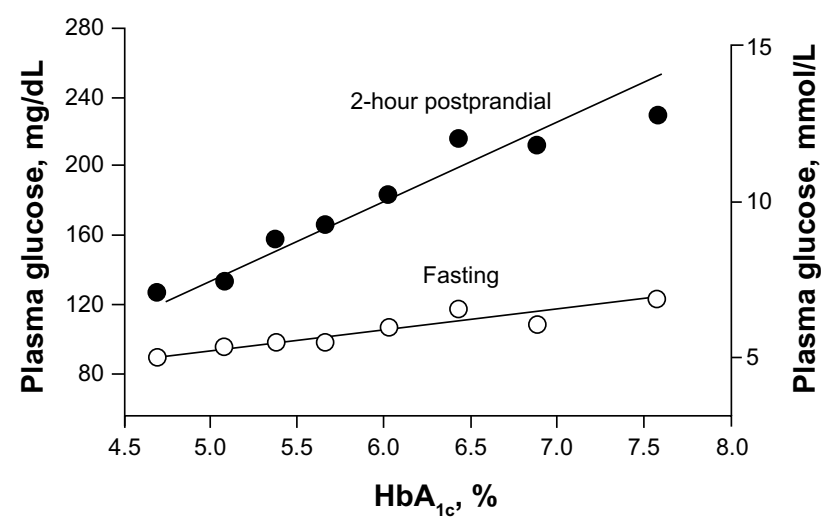

Figure I Relationship between increases in $\mathrm{HbA}_{\mathrm{lc}}$ levels and increases in fasting and 2-hour postprandial glucose levels in 175 volunteers with normal glucose tolerance, impaired glucose tolerance, or type 2 diabetes mellitus.

Abbreviation: $\mathrm{HbA}_{\mathrm{lc}}$, glycated hemoglobin.

order to maintain glucose homeostasis. In addition, most PPG metabolism occurs via insulin-sensitive pathways; however, in the fasting state most glucose disposal is not dependent on insulin. Often by the time diabetes is diagnosed based on elevated FPG levels, $\beta$-cell function has decreased by approximately $50 \%{ }^{4,26}$

Hyperglycemia-induced oxidative stress has been proposed as the biological mechanism to explain the putative link between postprandial hyperglycemia and cardiovascular disease ${ }^{7,13,27-30}$ (Figure 2) ${ }^{31}$ Hyperglycemia is associated with an increase in mitochondrial superoxide production, which is accompanied by an increase in the production of nitric oxide resulting from uncoupling of endothelial nitric oxide synthase and inducible nitric oxide synthase..$^{27}$ Overproduction of superoxide leads to production of other reactive oxygen species, including the strong oxidant peroxynitrite, which causes oxidative damage to DNA. ${ }^{29}$ Peroxynitrite-induced DNA damage causes activation of the nuclear enzyme poly(adenosine diphosphate-ribose) polymerase, which induces a series of cellular responses that ultimately result in acute vascular endothelial dysfunction. ${ }^{29}$ Vascular endothelial dysfunction has been recognized as a key step in the early development of cardiovascular disease. ${ }^{28}$ Endothelial dysfunction results in an impairment of endothelium-dependent vasodilation, as well as an increase in proinflammatory, procoagulatory, and proliferative responses, all of which are associated with the development of atherosclerosis. ${ }^{29}$

The possible association between PPG control and reduction in adverse cardiovascular outcomes remains controversial. It has been observed that pharmacologic strategies that target PPG to slow the progression of type 2 diabetes have reduced cardiovascular morbidity and mortality. Compared with regular insulin, the fast-acting insulin aspart lowered postprandial hyperglycemia and also preserved flow-mediated vasodilation, which is lowered in the postprandial state in diabetic patients..$^{32}$ In a study of 175 drug-naive patients ( 93 male/82 female; age range 35-70 years) with type 2 diabetes, patients treated with the insulin secretagogue repaglinide experienced a greater regression of carotid intima-media thickness compared with patients treated with glyburide, another secretagogue associated with a lower efficacy in reducing postprandial hyperglycemia. ${ }^{33}$ In this study, carotid intima-media thickness regression was shown to be associated with changes in postprandial but not fasting hyperglycemia.

However, other pharmacologic agents used to lower PPG showed no significant improvement in cardiovascular outcomes. In contrast with the results found with repaglinide, ${ }^{33}$ the incidence of cardiovascular events on treatment with another insulin secretagogue, nateglinide (4,645 patients, 2,277 male/2,368 female; mean age $64 \pm 7$ years) was not significantly different from placebo (4,661 patients, 2,318 male/2,343 female; mean age $64 \pm 7$ years) in a patient population with impaired glucose tolerance and established cardiovascular disease or cardiovascular risk factors in the NAVIGATOR (Nateglinide and Valsartan in Impaired Glucose Tolerance Outcomes Research) study. ${ }^{34}$ While nateglinide has been shown to significantly lower PPG compared with placebo, ${ }^{35}$ post-meal glucose was higher in the nateglinide arm compared with placebo for up to 5 years post follow-up in the NAVIGATOR study. ${ }^{34}$ In the HEART2D (Hyperglycemia and Its Effect After Acute Myocardial Infarction on Cardiovascular Outcomes in Patients With Type 2 Diabetes Mellitus) study, the risk of a first primary cardiovascular event in patients with type 2 diabetes after acute myocardial infarction was not significantly different for patients treated with prandial insulin (557 patients, 356 male/201 female; mean age $61 \pm 10$ years) compared with basal insulin (558 patients, 350 male/208 female; mean age $61 \pm 10$ years); this trial was stopped for lack of efficacy. ${ }^{36}$ The HEART2D study may have been underpowered to detect differences in cardiovascular effects due to a low rate of cardiovascular events in the basal and prandial treatment arms. The study also reported low efficacy with respect to PPG (the predetermined difference of $2.5 \mathrm{mmol} / \mathrm{L}$ in postprandial hyperglycemia between treatment groups was not reached [mean difference at the end of the study: $0.8 \mathrm{mmol} / \mathrm{L}$ ]). ${ }^{37}$

Thus, prevention of the progression of diabetes and possibly further reduction of the risk of cardiovascular disease by treating postprandial hyperglycemia may not be 

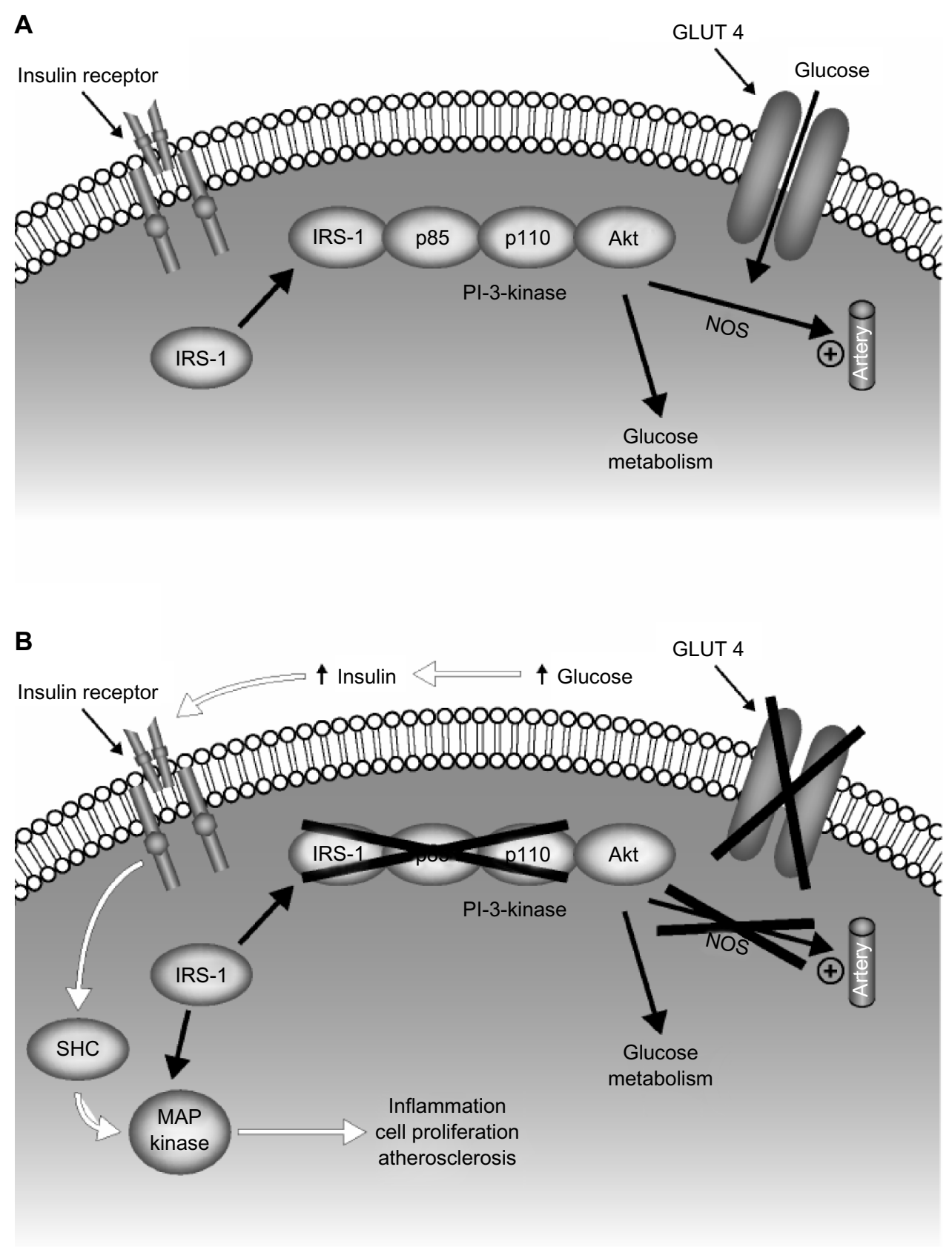

Figure 2 Cell mechanism linking impaired glucose utilization in type 2 diabetes and cardiovascular disease. Insulin signal transduction in individuals with normal glucose tolerance (A) and with type 2 diabetes (B). Insulin signaling through IRS-I is impaired in type 2 diabetes, leading to decreased glucose transport/phosphorylation/metabolism and impaired NOS activation/endothelial function. Insulin resistance in the IRS-I/PI-3 kinase pathway results in compensatory hyperinsulinemia, excessive stimulation of the MAP kinase pathway, and subsequent inflammation, cell proliferation, and atherogenesis.

Abbreviations: IRS-I, insulin-receptor substrate I; NOS, nitric oxide synthase; PI-3, phosphoinositide 3; MAP, mitogen-activated protein; SHC, Src-homology collagen.

straightforward with some agents and may be dependent on the extent of reduction of PPG.

It is important for clinicians to monitor and treat postprandial hyperglycemia in order to achieve optimal glycemic control. In patients who do not achieve their glycemic goals with oral agents that mainly affect fasting hyperglycemia (eg, metformin, sulfonylureas, and thiazolidinediones) and basal insulin, further titration of basal insulin or the addition of prandial insulin may result in unwanted consequences, such as hypoglycemia and weight gain. ${ }^{38}$ The addition of other complementary interventions, such as GLP-1 receptor agonists or DPP-4 inhibitors, to basal insulin therapy may improve glycemic control while avoiding the side effects of weight gain and hypoglycemia that may be associated with higher doses of insulin therapy. ${ }^{38,39}$ 


\section{Role of incretins \\ in glycemic regulation}

The intestinal incretin hormones GLP-1 and glucosedependent insulinotropic polypeptide (GIP) are released during absorption of meals and stimulate pancreatic $\beta$-cells to secrete insulin. ${ }^{40,41}$ It is estimated that GLP-1 and GIP are responsible for $50 \%-70 \%$ of postprandial insulin release. ${ }^{42}$ In addition, GLP-1 suppresses inappropriate glucagon secretion by pancreatic $\alpha$-cells, and at pharmacologic doses, delays gastric emptying by inhibiting gastroduodenal motility. The delay in gastric emptying caused by GLP-1 is associated with an increase in satiety and reduced food intake. ${ }^{40,43,44}$ Both GLP-1 and GIP are rapidly broken down by DPP-4 after secretion. ${ }^{45}$

In animal models and in some experiments using isolated human islets, GLP-1 has also been shown to stimulate proliferation and differentiation of pancreatic $\beta$ cells and to inhibit $\beta$-cell apoptosis. ${ }^{46,47}$ Thus, it has been postulated that incretin-based therapies may increase $\beta$-cell mass in patients with type 2 diabetes. ${ }^{43}$

\section{PPG-lowering effects of GLP-I receptor agonists and DPP-4 inhibitors}

Mechanistic and clinical data for the GLP-1 receptor agonists and DPP-4 inhibitors in reducing PPG are discussed herein, with recent clinical trial results summarized in Tables 1-4. Regarding the clinical trial data, searches of the US National Library of Medicine PubMed.gov database were conducted in October 2012 for each of the various agents (approved and investigational), focusing on English-language reports of randomized controlled trials published since 2008 as monotherapy (placebo-controlled trials only) or as add-on therapy to metformin, a sulfonylurea, or insulin therapy (placebo-controlled or active-controlled; of note, trials evaluating their use as initial combination therapy, rather than add-on therapy, are not covered here). The full text of identified articles was reviewed to identify those that reported on PPG outcomes (Tables 1-4). Selected data available in meeting abstract form were also considered.

\section{GLP-I receptor agonists}

Endogenous GLP-1 is impractical as a therapeutic agent for type 2 diabetes because it is rapidly broken down by DPP- $4 ;{ }^{41}$ however, several synthetic DPP-4-resistant GLP-1 analogs have been developed. ${ }^{40,41,43}$ These GLP-1 receptor agonists have the same actions as endogenous GLP-1. ${ }^{48}$
For patients with type 2 diabetes who have not responded to treatment with monotherapy or combination therapy using sulfonylureas or metformin, GLP-1 receptor agonists may have similar efficacy to that of insulin in lowering $\mathrm{HbA}_{10}$ levels, without weight gain or hypoglycemia. ${ }^{49}$

The 2012 ADA/EASD position statement for the management of hyperglycemia in patients with type 2 diabetes mellitus indicates that GLP-1 agonists may be considered at multiple points throughout treatment. ${ }^{17}$ This is in contrast with the earlier 2009 ADA/EASD consensus algorithm, which indicated that GLP-1 agonists be considered as add-on therapy for patients who fail initial treatment with metformin and lifestyle interventions alone. ${ }^{50,51}$ In the 2012 ADA/ EASD position statement, ${ }^{17}$ GLP-1 receptor agonists can be considered as initial drug monotherapy when metformin cannot be used and weight loss is seen as an essential part of therapy, as add-on to metformin after considering starting $\mathrm{HbA}_{1 \mathrm{c}}$, and as part of several three-drug or four-drug combinations that exclude DPP-4 inhibitors (eg, combination of metformin and a GLP-1 receptor agonist with a sulfonylurea or thiazolidinedione with or without basal insulin). At all points, the risk of hypoglycemia and other side effects, the importance of weight loss, and costs are considered on an individual basis.

There are currently three GLP-1 analogs, ie, exenatide (Byetta $^{\circledR}$; Amylin Pharmaceuticals Inc, San Diego, CA, USA), ${ }^{52}$ a long-acting release formulation of exenatide, exenatide LAR (Bydureon ${ }^{\circledR}$; Amylin Pharmaceuticals Inc, San Diego, CA, USA), ${ }^{53}$ and liraglutide (Victoza ${ }^{\circledR}$; Novo Nordisk A/S, Bagsvaerd, Denmark ${ }^{54}$ ), that are approved in the US for the treatment of type 2 diabetes. ${ }^{55}$

Exenatide is a synthetic incretin mimetic that has 53\% homology with endogenous human GLP- $1 ; 56$ because it is resistant to degradation by DPP-4; however, exenatide has a longer circulating half-life than endogenous GLP-1. Exenatide binds to GLP-1 receptors on pancreatic $\beta$-cells and augments glucose-mediated insulin secretion. ${ }^{43,50}$ Cervera et al studied the mechanism of action by which exenatide (12 patients, nine male/three female; mean age $44 \pm 2$ years) reduces PPG concentration and found that by decreasing endogenous (mostly hepatic) glucose production by approximately $50 \%$ and by delaying gastric emptying, exenatide significantly reduces postprandial hyperglycemia. ${ }^{57}$ Approximately one third of the reduction in postprandial hyperglycemia was due to delayed gastric emptying and enhanced splanchnic glucose uptake. ${ }^{57}$ Another one third of the reduction was due to inhibition of glucagon secretion, and one third was due to stimulation of insulin secretion in pancreatic $\beta$-cells. ${ }^{57}$ 


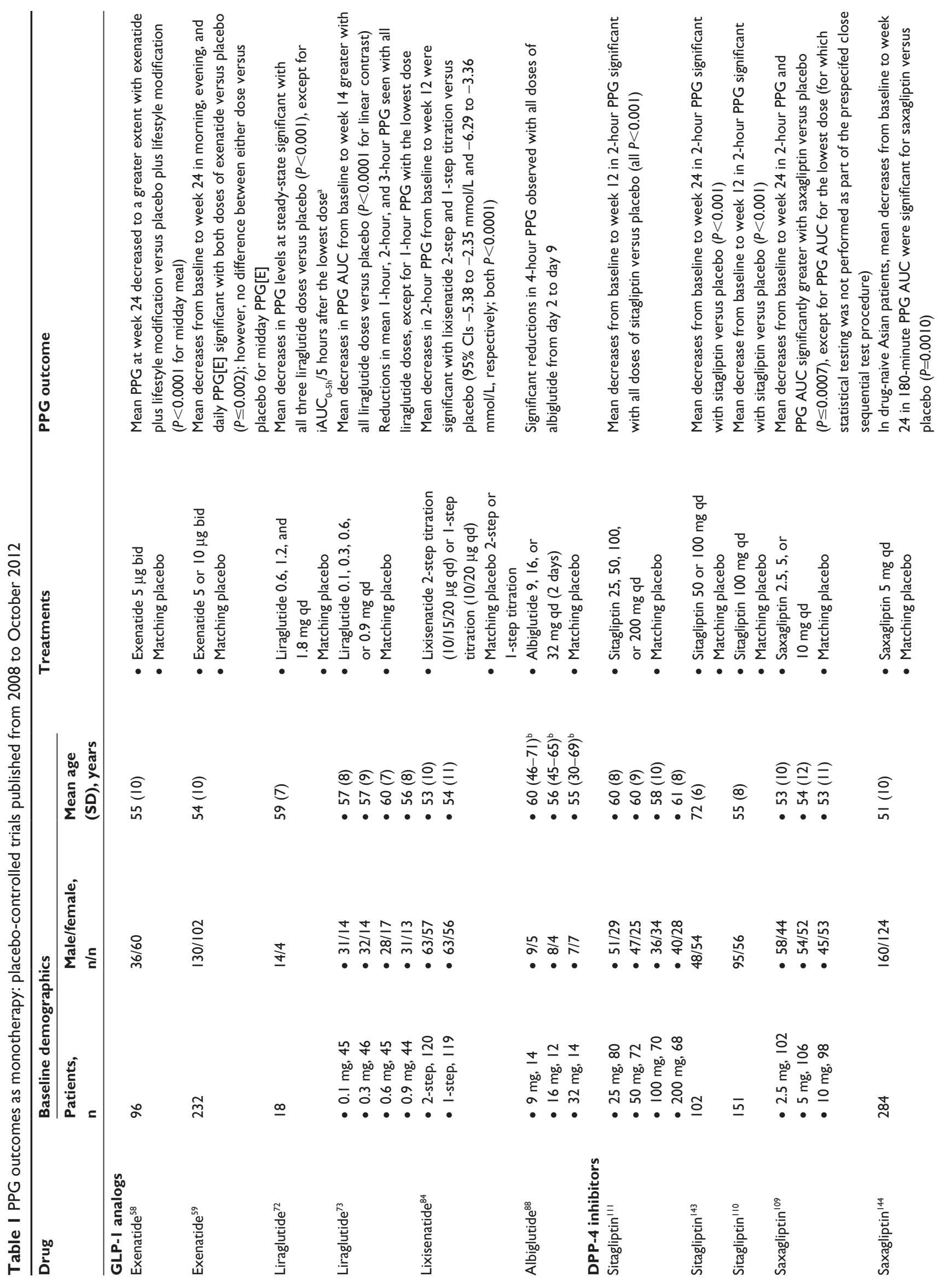



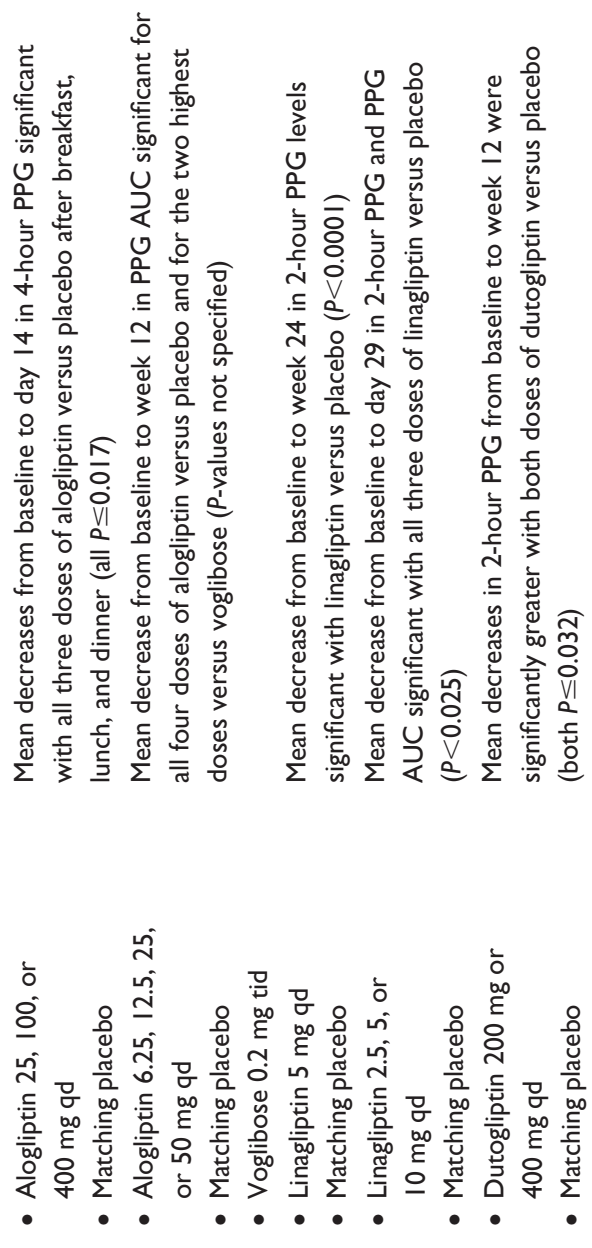

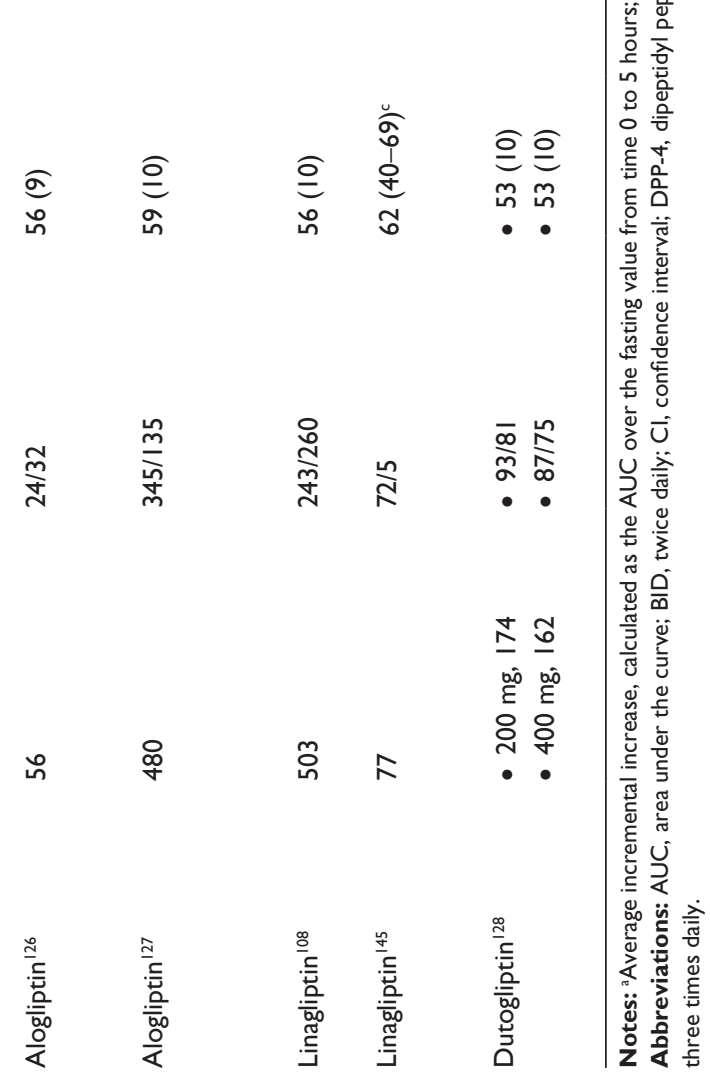

Gastrointestinal side effects are relatively common with exenatide; $30 \%-45 \%$ of patients experience one or more episodes of nausea, vomiting, or diarrhea; however, these side effects usually lessen over time. ${ }^{50}$

Recent clinical trial publications have described the activity of exenatide in reducing PPG as monotherapy (Table $1^{58,59}$ ) or as add-on therapy to metformin (Table $2^{60-63}$ ) or insulin (Table $4^{64}$ ). Pooled data from clinical trials of exenatide as add-on therapy with metformin and/or sulfonylurea show that exenatide injected twice daily reduces mean PPG concentrations compared with placebo (Table 2). When twice-daily injections of exenatide were added to basal insulin (insulin glargine) alone or in combination with metformin and/or pioglitazone, patients with type 2 diabetes had improved glycemic control compared with placebo. $\mathrm{HbA}_{1 \mathrm{c}}$ decreased by $1.74 \%$ with exenatide versus $1.04 \%$ with placebo $(P<0.001)$, and morning and evening 2-hour postprandial excursions were significantly reduced (both $P<0.001$ ), without increases in hypoglycemia or weight gain. ${ }^{64}$ However, addition of exenatide increased the incidence of nausea, diarrhea, vomiting, and headache, and a higher percentage of patients in the exenatide group (9\%) withdrew from the study because of adverse events than in the placebo group (1\%). ${ }^{64}$

In the extended-release formulation of exenatide (exenatide LAR), exenatide is encapsulated in polymerbased microspheres that are injected on a once-weekly basis; these microspheres slowly degrade over time, releasing exenatide in a slow, controlled manner over the course of a week. ${ }^{51,53}$ In a study by Drucker et al (DURATION-1), exenatide LAR $2 \mathrm{mg}$ once weekly (148 patients, 82 male/66 female; mean age $55 \pm 10$ years) was compared with exenatide $10 \mu \mathrm{g}$ twice daily (147 patients, 75 male/72 female; mean age $55 \pm 10$ years) in a randomized, open-label, noninferiority trial. ${ }^{65}$ In the DURATION-1 study, a higher percentage of patients who received exenatide once a week (77\%) achieved $\mathrm{HbA}_{1 \mathrm{c}}$ values of $7 \%$ or less than patients who received exenatide twice daily $(61 \% ; P=0.0039)$ after 30 weeks of treatment. Compared with exenatide $10 \mu \mathrm{g}$ twice daily, exenatide LAR $2 \mathrm{mg}$ once weekly resulted in significantly greater reductions in $\mathrm{HbA}_{1 \mathrm{c}}(-1.9 \%$ versus $-1.5 \%, P=0.0023)$ without increasing the risk of hypoglycemia and provided similar weight loss benefits; however, exenatide twice daily was associated with significantly greater reductions in 2-hour PPG from baseline to week 14 compared with exenatide LAR $(-125.96 \mathrm{mg} / \mathrm{dL}$ versus $-95.88 \mathrm{mg} / \mathrm{dL} ; P=0.0124) .{ }^{65}$ Results from the DURATION-5 study confirm the findings from DURATION-1, showing that exenatide LAR once weekly 


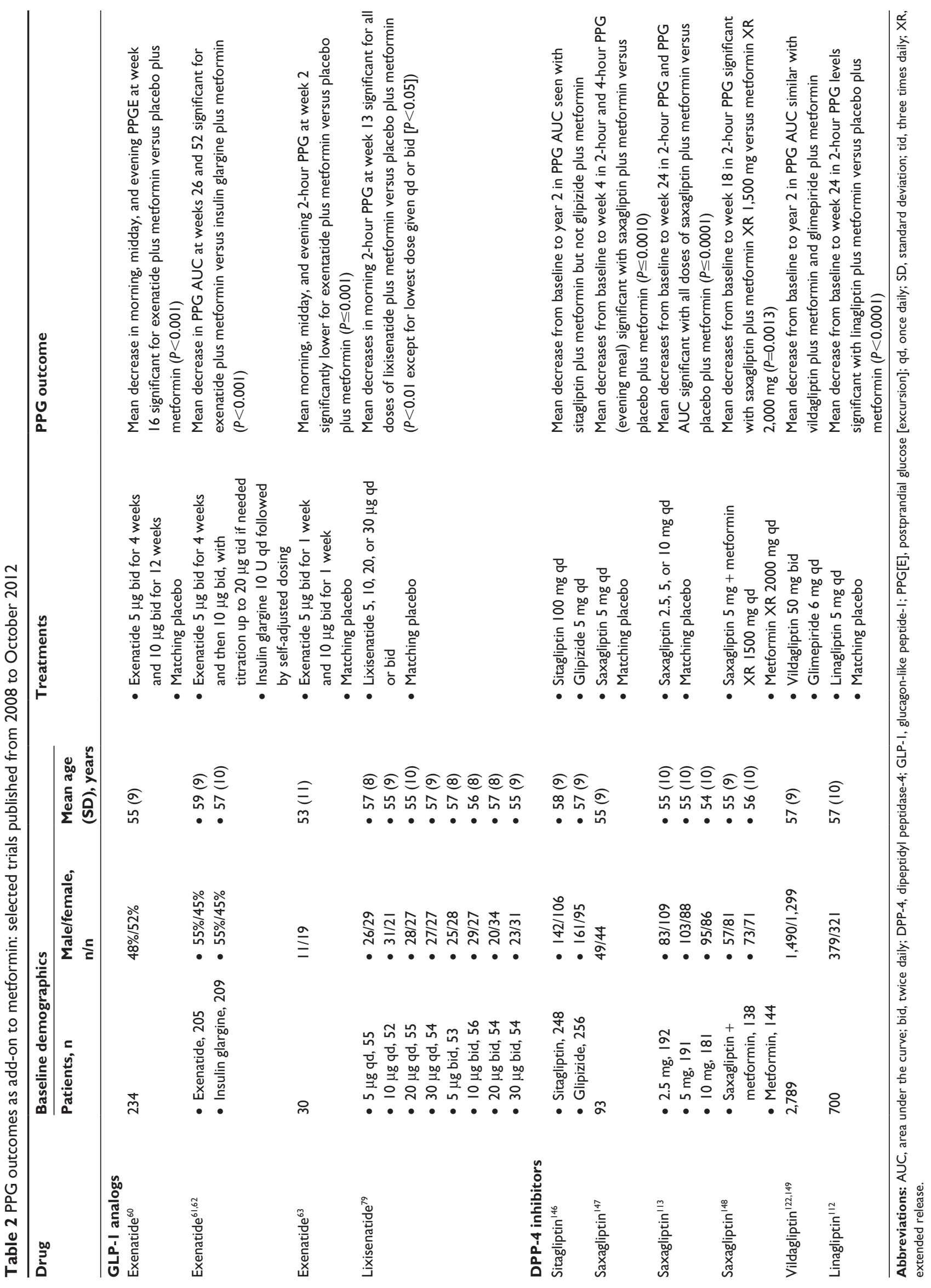


Table 3 PPG outcomes as add-on to a sulfonylurea: trials published from 2008 to October 2012

\begin{tabular}{|c|c|c|c|c|c|}
\hline \multirow[t]{2}{*}{ Drug } & \multicolumn{3}{|c|}{ Baseline demographics } & \multirow[t]{2}{*}{ Treatments } & \multirow[t]{2}{*}{ PPG outcome } \\
\hline & Patients, $\mathbf{n}$ & $\begin{array}{l}\text { Male/female, } \\
n / n\end{array}$ & $\begin{array}{l}\text { Mean age } \\
\text { (SD), years }\end{array}$ & & \\
\hline \multicolumn{6}{|l|}{ GLP-I analogs } \\
\hline Liraglutide $^{75}$ & 264 & $169 / 95$ & $60(10)$ & $\begin{array}{l}\text { - Liraglutide } 0.6 \text { or } \\
0.9 \text { mg qd } \\
\text { - Matching placebo }\end{array}$ & $\begin{array}{l}\text { Mean decreases from baseline to } \\
\text { week } 24 \text { in PPG AUC significant with } \\
\text { both liraglutide doses versus placebo } \\
(P<0.000 \text { I), as add-on to glibenclamide, } \\
\text { glicazide, or glimeprimide }\end{array}$ \\
\hline \multicolumn{6}{|c|}{ DPP-4 inhibitors } \\
\hline Saxagliptin 115,116 & $\begin{array}{l}\text { - } 2.5 \mathrm{mg}, 248 \\
\text { - } 5 \mathrm{mg}, 253\end{array}$ & $\begin{array}{l}\text { - } 113 / 135 \\
\text { - } 110 / 143\end{array}$ & $\begin{array}{l}\text { - } 55(10) \\
\text { - } 55(10)\end{array}$ & $\begin{array}{l}\text { - Saxagliptin } 2.5 \text { or } \\
5 \text { mg qd } \\
\text { - Matching placebo }\end{array}$ & $\begin{array}{l}\text { Mean decreases from baseline to } \\
\text { week } 24 \text { in } 2 \text {-hour PPG and PPG } \\
\text { AUC significant with saxagliptin plus } \\
\text { uptitrated glyburide versus placebo } \\
\text { plus uptitrated glyburide }(P<0.000 \text { I); } \\
\text { updated data at week } 76 \text { data were } \\
\text { consistent with those at week } 24\end{array}$ \\
\hline Vildagliptin ${ }^{123}$ & $\begin{array}{l}\text { - Vildagliptin }+ \\
\text { glimepiride, } 85 \\
\text { - Vildagliptin }+ \\
\text { pioglitazone, } 83\end{array}$ & $\begin{array}{l}\text { - } 43 / 42 \\
\text { - } 42 / 41\end{array}$ & $\begin{array}{l}\text { - } 58(5) \\
\text { - } 59(6)\end{array}$ & $\begin{array}{l}\text { - Vildagliptin } 50 \mathrm{mg} \text { bid + } \\
\text { glimepiride } 2 \mathrm{mg} \text { tid } \\
\text { - Vildagliptin } 50 \mathrm{mg} \text { bid + } \\
\text { pioglitazone } 30 \mathrm{mg} \text { qd }\end{array}$ & $\begin{array}{l}\text { Mean decreases from baseline to } \\
\text { months } 9 \text { and } 12 \text { in PPG were } \\
\text { significant in both groups, with no } \\
\text { significant differences between groups }\end{array}$ \\
\hline Vildagliptin ${ }^{124}$ & $\begin{array}{l}\text { - } 50 \text { mg qd, I32 } \\
\text { - } 50 \text { mg bid, I } 32\end{array}$ & $\begin{array}{l}\text { - } 78 / 54 \\
\text { - } 79 / 53\end{array}$ & $\begin{array}{l}\text { - } 59(\mathrm{II}) \\
\text { - } 58(\mathrm{II})\end{array}$ & $\begin{array}{l}\text { - Vildagliptin } 50 \mathrm{mg} \\
\text { qd or bid } \\
\text { - Matching placebo }\end{array}$ & $\begin{array}{l}\text { Mean decreases from baseline to week } \\
24 \text { in } P P G[E] \text { significant for vildagliptin } \\
50 \mathrm{mg} \text { plus glimepiride versus placebo } \\
\text { plus glimepiride }(P=0.008 \text {; significance } \\
\text { not reached for } 100 \mathrm{mg} \text { dose versus } \\
\text { placebo }[P=0.085])\end{array}$ \\
\hline
\end{tabular}

Abbreviations: AUC, area under the curve; bid, twice daily; DPP-4, dipeptidyl peptidase-4; GLP-I, glucagon-like peptide-I; PPG[E], postprandial glucose [excursion]; qd, once daily; SD, standard deviation; tid, three times daily.

Table 4 PPG outcomes as add-on to insulin: trials published from 2008 to October 2013

\begin{tabular}{|c|c|c|c|c|c|}
\hline \multirow[t]{2}{*}{ Drug } & \multicolumn{3}{|c|}{ Baseline demographics } & \multirow[t]{2}{*}{ Treatments } & \multirow[t]{2}{*}{ PPG outcome } \\
\hline & $\begin{array}{l}\text { Patients, } \\
\text { n }\end{array}$ & $\begin{array}{l}\text { Male/female, } \\
\mathrm{n} / \mathrm{n}\end{array}$ & $\begin{array}{l}\text { Mean age } \\
\text { (SD), years }\end{array}$ & & \\
\hline \multicolumn{6}{|c|}{ GLP-I analogs } \\
\hline Exenatide $^{64}$ & 137 & $70 / 67$ & $59(9)$ & $\begin{array}{l}\text { - Exenatide } 10 \mu g \text { bid } \\
\text { - Matching placebo }\end{array}$ & $\begin{array}{l}\text { Mean decrease from baseline to week } 30 \text { in morning } \\
\text { and evening 2-hour PPG significant with exenatide } \\
\text { plus insulin glargine versus placebo plus insulin glargine } \\
(P<0.00 \text { I); however, no significant difference in midday } \\
\text { 2-hour PPG }\end{array}$ \\
\hline Lixisenatide $^{80}$ & 495 & $228 / 267$ & $57(10)$ & $\begin{array}{l}\text { - Lixisenatide } 20 \mu g \text { qd } \\
\text { - Matching placebo }\end{array}$ & $\begin{array}{l}\text { Mean decrease from baseline to week } 24 \text { in } 2 \text {-hour } \\
\text { postbreakfast PPG significant with lixisenatide plus } \\
\text { basal insulin } \pm \text { metformin versus placebo plus basal } \\
\text { insulin } \pm \text { metformin }(P<0.000 \text { I) }\end{array}$ \\
\hline Lixisenatide ${ }^{85}$ & 154 & $69 / 85$ & $59(10)$ & $\begin{array}{l}\text { - Lixisenatide } 20 \mu \mathrm{g} \text { qd } \\
\text { - Matching placebo }\end{array}$ & $\begin{array}{l}\text { Mean decrease from baseline to week } 24 \text { in } 2 \text {-hour } \\
\text { PPG significant with lixisenatide plus basal insulin } \pm \\
\text { sulfonylurea versus placebo plus basal insulin } \pm \\
\text { sulfonylurea }(P<0.000 \text { I) }\end{array}$ \\
\hline \multicolumn{6}{|c|}{ DPP-4 inhibitors } \\
\hline Sitagliptin 119 & 322 & $157 / 165$ & $58(9)$ & $\begin{array}{l}\text { - Sitagliptin } 100 \text { mg qd } \\
\text { - Matching placebo }\end{array}$ & $\begin{array}{l}\text { Mean decrease from baseline to week } 24 \text { in } 2 \text {-hour } \\
\text { PPG significant with sitagliptin plus insulin } \pm \text { metformin } \\
\text { versus placebo plus insulin } \pm \text { metformin }(P \leq 0.00 \text { I })\end{array}$ \\
\hline Saxagliptin 117 & 304 & $120 / 184$ & $57(9)$ & $\begin{array}{l}\text { - Saxagliptin } 5 \text { mg qd } \\
\text { - Matching placebo }\end{array}$ & $\begin{array}{l}\text { Mean decrease from baseline to week } 24 \text { in } 180 \text {-minute } \\
\text { and I } 20 \text {-minute PPG significant with saxagliptin plus } \\
\text { insulin } \pm \text { metformin versus placebo plus insulin } \pm \\
\text { metformin ( } P=001 \mathrm{I} \text { and } P=0.0016 \text {, respectively) }\end{array}$ \\
\hline
\end{tabular}

Abbreviations: AUC, area under the curve; bid, twice daily; DPP-4, dipeptidyl peptidase-4; GLP-I, glucagon-like peptide-I; PPG, postprandial glucose; qd, once daily; $\mathrm{SD}$, standard deviation; tid, three times daily. 
(129 patients, 77 male/52 female; mean age $56 \pm 11$ years) was associated with significantly greater reductions in $\mathrm{HbA}_{1 \mathrm{c}}$ compared with exenatide twice daily (123 patients, 68 male/55 female; mean age $55 \pm 10$ years) over 24 weeks of treatment $(-1.6 \%$ versus $-0.9 \%, P<0.0001)$; however, PPG was not measured in DURATION-5. ${ }^{66}$ Overall, there were six DURATION studies that all had similar outcomes, showing that exenatide once weekly resulted in significant improvements in glycemic control with no increased risk of hypoglycemia. ${ }^{65-70}$

Liraglutide is a nonprandial (long-acting) GLP-1 receptor agonist showing 97\% sequence homology with human GLP-1, ${ }^{71}$ with recent clinical trial data supporting its efficacy in reducing PPG as monotherapy (Table $1^{72-74}$ ) or as add-on therapy to a sulfonylurea (Table $3^{75,76}$ ). A study by Garber et al (Liraglutide versus glimepiride monotherapy for type 2 diabetes [LEAD-3]) comparing liraglutide $1.2 \mathrm{mg}$ (251 patients, 117 male/134 female; mean age $54 \pm 11$ years) and liraglutide $1.8 \mathrm{mg}$ ( 247 patients, 121 male/126 female; mean age $52 \pm 11$ years) versus glimepiride $8.0 \mathrm{mg}$ (248 patients, 133 male/115 female; mean age $53 \pm 11$ years) monotherapy in 746 patients with type 2 diabetes who were either drug-naïve or treated with oral antidiabetic drugs found that liraglutide resulted in significantly greater reductions in mean $\mathrm{HbA}_{1 \mathrm{c}}$ (liraglutide $1.2 \mathrm{mg}, 0.84 \%[P<0.0001]$; liraglutide $1.8 \mathrm{mg}, 1.14 \%$ $[P=0.0014])$ compared with glimepiride $8.0 \mathrm{mg}(0.51 \%) .{ }^{74}$ Additionally, compared with glimepiride, patients treated with liraglutide had significantly greater reductions in FPG (1.2 mg, $P=0.027 ; 1.8 \mathrm{mg}, P=0.0001)$ and PPG (1.8 mg, $P=0.0038$ ) levels. ${ }^{74}$ In a study by Buse et al (LEAD-6) evaluating 464 patients with type 2 diabetes who were inadequately controlled with metformin, sulfonylurea, or a combination of the two, the addition of once-daily liraglutide (233 patients, 114 male/119 female; mean age $56 \pm 10$ years) resulted in significantly greater reductions in mean $\mathrm{HbA}_{1 \mathrm{c}}(-1.12 \%$ versus $-0.79 \% ; P<0.0001)$ and mean FPG $(-1.61 \mathrm{mmol} / \mathrm{L}$ versus $-0.60 \mathrm{mmol} / \mathrm{L} ; P<0.0001)$ than the addition of twice-daily exenatide (231 patients, 127 male/104 female; mean age $57 \pm 11$ years). ${ }^{76}$ In contrast, treatment with twice-daily exenatide resulted in significantly greater reductions in mean PPG after breakfast and dinner ( $P \leq 0.0005$ for both comparisons).${ }^{76}$ Similar to exenatide, the most common adverse events associated with liraglutide are gastrointestinal disorders, including nausea, vomiting, and diarrhea. ${ }^{71,76}$ Liraglutide treatment was associated with increased rates of thyroid medullary carcinoma in preclinical toxicology studies, ${ }^{77}$ and liraglutide therapy is contraindicated in patients with a personal or family history of thyroid medullary cancer. ${ }^{54}$

Several additional GLP-1 analogs are in development, including lixisenatide and albiglutide, which are discussed below. The GLP-1 analog taspoglutide, for which clinical development was discontinued in 2010, will not be discussed.

\section{Lixisenatide}

Lixisenatide once daily is a highly potent and selective prandial (short-acting) GLP-1 receptor agonist that is currently in development for the treatment of type 2 diabetes, and was recently (February 2013) granted marketing authorization by the European Medicines Agency. In preclinical studies, the binding affinity of lixisenatide for the GLP-1 receptor was approximately four times stronger than that of human GLP-1. In preclinical pharmacology studies, lixisenatide has been shown to: protect pancreatic $\beta$-cells from apoptosis; improve glucose-stimulated pancreatic insulin secretion; preserve pancreatic responsiveness, insulin mRNA expression, and $\beta$-cell mass; improve oral glucose tolerance; delay gastric emptying; and decrease overall food intake. All of these actions suggest that lixisenatide has the potential to markedly improve glucose homeostasis and slow the progression of type 2 diabetes. ${ }^{78}$

A dose-ranging study evaluated the efficacy and safety of lixisenatide as add-on therapy in 542 patients with type 2 diabetes inadequately controlled with metformin; oncedaily lixisenatide significantly reduced mean 2-hour PPG compared with placebo ( $P<0.05$ for all doses tested) over 13 weeks of treatment (Table 2 ). In addition, patients treated with lixisenatide $20 \mu \mathrm{g}$ once daily experienced significant reductions from baseline in body weight, and more than two thirds of patients achieved the target $\mathrm{HbA}_{1 \mathrm{c}}$ level of $<7 \%$, with an optimal risk-benefit ratio versus other doses and regimens. ${ }^{79}$

The GetGoal Phase III clinical development program has evaluated the efficacy and safety of once-daily lixisenatide across the disease spectrum: as monotherapy in patients insufficiently controlled despite diet and exercise (GetGoalMono), to those treated with one or two other oral antidiabetic agents (GetGoal-M, GetGoal-S, and GetGoal-P), to the insulin-naïve patients (GetGoal Duo-1), as well as in patients on an established insulin regimen (GetGoal-L and GetGoalL-Asia). In this program, lixisenatide has consistently demonstrated significant reductions in $\mathrm{HbA}_{1 \mathrm{c}}$ (by $0.32 \%-0.88 \%$ versus placebo) and PPG levels, and has been shown to have a beneficial effect on weight as well as tolerability profiles 
commonly characterized by adverse events of mild transient nausea and vomiting. ${ }^{80-87}$

As monotherapy in the GetGoal-Mono study, both $\mathrm{HbA}_{1 \mathrm{c}}$ and 2-hour PPG levels decreased significantly $(P<0.001)$ over the 12-week course of treatment with lixisenatide compared with placebo (Table 1), and significant improvements in FPG compared with placebo were observed for both doses of lixisenatide (two-step titration of 10/15/20 $\mu$ g once daily and one-step titration of $10 / 20 \mu$ g once daily). ${ }^{84}$ Similar improvements in $\mathrm{HbA}_{1 \mathrm{c}}$ and PPG levels were demonstrated for lixisenatide in patients whose type 2 diabetes was insufficiently controlled while on metformin in the GetGoal-M study and on a sulfonylurea with or without metformin in the GetGoal-S study. ${ }^{86,87}$ In the GetGoal-P study, addition of once-daily lixisenatide in patients with type 2 diabetes poorly controlled with pioglitazone with or without metformin resulted in significantly greater reductions in $\mathrm{HbA}_{1 \mathrm{c}}$, and a significantly higher percentage of patients achieved an $\mathrm{HbA}_{1 \mathrm{c}}<7.0 \%$ (52\% versus $\left.26 \% ; P<0.0001\right) .{ }^{81}$

Evaluation of lixisenatide as add-on in patients suboptimally controlled on basal insulin with or without metformin in the GetGoal-L study and with sulfonylurea in the GetGoal-L-Asia study showed that lixisenatide significantly reduced $\mathrm{HbA}_{1 \mathrm{c}}$ and 2-hour PPG compared with placebo (Table 4). Lixisenatide also had favorable effects on body weight (least-squares mean difference versus placebo for GetGoal-L, $-1.28 \mathrm{~kg}[P<0.001]$ and for GetGoal-LAsia, $-0.43 \mathrm{~kg}[P=0.0857]) .{ }^{80,85}$ Similarly, in the GetGoalDuo 1 study (898 patients, 466 male/432 female; mean age $56 \pm 10$ years), once-daily lixisenatide added to consistently titrated insulin glargine plus metformin with or without a thiazolidinedione significantly improved $\mathrm{HbA}_{1 \mathrm{c}}$ and 2-hour PPG compared with placebo, with significant weight reduction (least-squares mean difference versus placebo, $-0.89 \mathrm{~kg} ; P=0.0012$ ) and a significantly higher percentage of patients achieving $\mathrm{HbA}_{1 \mathrm{c}}<7.0 \%$ (lixisenatide, 56\%; placebo, $39 \% ; P=0.0001){ }^{82}$

\section{Albiglutide}

Albiglutide is a GLP-1 receptor agonist that consists of a DPP-4-resistant GLP-1 dimer fused to recombinant human albumin. ${ }^{88}$ Albiglutide has a half-life of approximately 5 days, which may allow for weekly or less frequent dosing. ${ }^{89}$ Albiglutide does not cross the blood-brain barrier in a GLP-1 receptor-independent manner as does native GLP-1 $1^{90,91}$ and the smaller GLP-1 analogs exenatide ${ }^{92}$ and liraglutide, ${ }^{93}$ which may improve its gastrointestinal tolerability. ${ }^{89,94}$
In a randomized, single-blind, dose-escalation study in patients with type 2 diabetes $(n=54)$, albiglutide consistently reduced FPG and PPG concentrations in a dose-dependent manner (Table 1). The safety profile of albiglutide was similar to that of placebo. Headache and nausea were the most frequently reported adverse events. ${ }^{88}$ In a separate randomized, double-blind, placebo-controlled, and active-controlled study, significant reductions were observed in mean $\mathrm{HbA}_{1 \mathrm{c}}$ levels compared with placebo in patients who received albiglutide $30 \mathrm{mg}$ weekly, $50 \mathrm{mg}$ biweekly, or $100 \mathrm{mg}$ monthly (all $P<0.05$ ); reductions in mean $\mathrm{HbA}_{1 \mathrm{c}}$ levels with these doses of albiglutide were approximately $25 \%-30 \%$ greater than those observed with twice-daily exenatide. ${ }^{89}$ In addition, patients who received albiglutide lost an average of $1.1-1.6 \mathrm{~kg}$; weight loss on albiglutide treatment was numerically higher than on placebo (average weight loss, $0.7 \mathrm{~kg}$ ) but numerically lower than on exenatide treatment (average weight loss, $2.4 \mathrm{~kg}$ ). ${ }^{89}$

Results from the HARMONY 6 and 7 trials for albiglutide were recently reported. ${ }^{95-97}$ In HARMONY 6, albiglutide demonstrated noninferiority to preprandial insulin lispro as add-on treatment to insulin glargine, with clinically significant reductions in $\mathrm{HbA}_{1 \mathrm{c}}$ from baseline $(-0.82 \%$ versus $-0.66 \%$ ) concomitant with weight loss compared with baseline $(-0.73 \mathrm{~kg}$ versus $+0.81 \mathrm{~kg})$ after 26 weeks of treatment. ${ }^{95}$ Patients who completed 52 weeks of treatment in HARMONY 6 had further reductions in $\mathrm{HbA}_{1 \mathrm{c}}$ from baseline $(-1.01 \%$ versus $-0.84 \%)$, with sustained weight changes. ${ }^{97}$ In the 32-week HARMONY 7 trial, albiglutide demonstrated a significant reduction in $\mathrm{HbA}_{1 \mathrm{c}}$ from baseline but did not meet the endpoint of noninferiority compared with liraglutide $(-0.78 \%$ versus $-0.99 \%) .{ }^{96}$ Albiglutide also resulted in a smaller difference in weight loss $(-0.64 \mathrm{~kg}$ versus $-2.2 \mathrm{~kg})$, but with fewer gastrointestinal adverse events.

\section{Comparison of the GLP-I analogs}

The prandial GLP-1 analogs (twice-daily exenatide and oncedaily lixisenatide) lower $\mathrm{HbA}_{1 \mathrm{c}}$ primarily by targeting $\mathrm{PPG}$, while the nonprandial GLP-1 analogs (liraglutide, exenatide LAR, and albiglutide) primarily target FPG. ${ }^{65,76,84,87,89,98}$ Exenatide LAR $2 \mathrm{mg}$ once weekly had a greater effect on FPG (least-squares mean [standard error] for exenatide LAR, -2.3 [0.2] $\mathrm{mmol} / \mathrm{L}$; for exenatide twice daily, -1.4 [0.2] mmol/L) and a lesser effect on PPG (least-squares mean [standard error] for exenatide LAR, -5.3 [0.5] $\mathrm{mmol} / \mathrm{L}$; for exenatide twice daily, $-6.9 \mathrm{mmol} / \mathrm{L}$ ) compared with exenatide $10 \mu \mathrm{g}$ twice daily after 30 weeks of treatment. ${ }^{65}$ In a 26-week, direct-comparison trial with exenatide and liraglutide, exenatide had a higher effect on PPG reduction (estimated 
treatment difference: $1.33 \mathrm{mmol} / \mathrm{L}$, breakfast, $P<0.0001$; $1.01 \mathrm{mmol} / \mathrm{L}$, dinner, $P<0.0005$ ), while liraglutide had a larger effect on FPG reduction (estimated treatment difference, $-1.01 \mathrm{mmol} / \mathrm{L}, P<0.0001) .{ }^{76}$ The once-daily prandial lixisenatide, which primarily targets $\mathrm{PPG}$, has consistently provided significant improvements in glycemic control as well as reductions in body weight when administered as monotherapy, ${ }^{84}$ as add-on treatment to metformin ${ }^{99}$ or sulfonylurea \pm metformin, ${ }^{86}$ and as add-on therapy to insulin \pm metformin.$^{85}$ Results from one study showed that the glycemic effects of lixisenatide were superior to those of liraglutide. ${ }^{100}$ In this study, 2-hour PPG levels $<140 \mathrm{mg} / \mathrm{dL}$ were reported by a higher percentage of patients who received lixisenatide (69\%) than liraglutide (29\%), and lixisenatide treatment resulted in a significantly greater decrease in postmeal glucagon than liraglutide $(P=0.032) .{ }^{100}$ Further, efficacy results from the GetGoal-L ${ }^{80}$ and GetGoal-Duo $1^{82}$ studies support the clinical rationale for combination of lixisenatide with basal insulin to improve glycemic control by reducing both PPG and FPG.

The gastric emptying effect of GLP-1, which lowers PPG, has been shown to decrease after chronic administration (tachyphylaxis) of intravenous GLP-1 in healthy human subjects. ${ }^{101} \mathrm{An}$ area that remains to be investigated is whether tachyphylaxis occurs with GLP-1 analogs and if the longterm efficacy in reducing PPG varies for different GLP-1 analogs due to different dosing regimens and/or duration of action. If confirmed, the tachyphylaxis hypothesis could partially explain the differential effects of GLP-1 receptor agonists on FPG and PPG.

\section{DPP-4 inhibitors}

DPP-4 inhibitors decrease the metabolism of GLP-1 and GIP through inhibition of the DPP-4 enzyme, which under normal physiologic conditions cleaves the two end-terminal amino acids of GLP-1 and GIP to rapidly inactivate these hormones. ${ }^{102}$ By prolonging the action of GLP-1, DPP-4 inhibitors improve both $\alpha$-cell and $\beta$-cell responsiveness to glucose. ${ }^{103}$ Inhibition of DPP-4 increases prandial insulin secretion and suppresses glucagon secretion, thereby decreasing hepatic glucose production and improving peripheral glucose uptake, which decreases PPG in patients with type 2 diabetes. ${ }^{55,102,104}$ For DPP-4 inhibitors to be effective, some residual insulin secretion must remain. ${ }^{7}$ The DPP-4 inhibitors that are currently approved or in development for the treatment of type 2 diabetes all have convenient oral dosing, along with a low risk of hypoglycemia and weight gain. ${ }^{41,55,103}$ Similar to GLP-1 agonists, the ADA/
EASD 2012 position statement on diabetes treatment recommendations includes DPP-4 inhibitors as an option for add-on therapy in patients who fail to reach their glycemic targets with metformin. ${ }^{17}$

Three DPP-4 inhibitors, sitagliptin (Januvia ${ }^{\circledR}$; Merck and Co, Inc, Whitehouse Station, NJ, USA), saxagliptin (Onglyza $^{\circledR}$; Bristol-Myers Squibb, New York, NY, USA), and linagliptin (Tradjenta ${ }^{\circledR}$; Boehringer Ingelheim Pharmaceuticals Inc, Ridgefield, CT, and Eli Lilly and Company, Indianapolis, IN, USA) are approved in the US as oral antidiabetic therapies; ${ }^{105-107}$ other agents in clinical development are discussed individually below.

Linagliptin, the newest of these agents, is a potent and selective xanthine-based DPP-4 inhibitor with a long duration of action; more than $80 \%$ inhibition of DPP-4 is still present 24 hours after dosing. Across a number of recently published placebo-controlled trials, the PPG-lowering effects of each of the three approved agents as monotherapy (Table 1) 108-110 $^{10}$ as add-on therapy to metformin (Table 2) $)^{11-114}$ have been described, with additional data available for saxagliptin as add-on therapy to a sulfonylurea (Table 3$)^{15,116}$ and insulin with or without metformin (Table 4); ${ }^{117,118}$ sitagliptin as add-on therapy to insulin or the combination of insulin plus metformin (Table 4), ${ }^{119}$ and linagliptin as add-on therapy to basal insulin. ${ }^{120}$ Sitagliptin, saxagliptin, and linagliptin have neutral effects on weight, do not cause hypoglycemia (although risk is increased when used as add-on therapy to a sulfonylurea or [for sitagliptin] with insulin), and are not associated with the gastrointestinal adverse event profiles characteristic of the GLP-1 receptor agonists. ${ }^{105-107}$ However, there have been postmarketing reports of pancreatitis and severe allergic or hypersensitivity reactions with both sitagliptin and saxagliptin. While results of recent clinical trials involving DPP-4 inhibitors indicate that they effectively reduce $\mathrm{HbA}_{1 \mathrm{c}}$ levels and improve pancreatic $\beta$-cell function, long-term data assessing the sustainability of glycemic control provided by these agents are not yet available. ${ }^{103}$

\section{Vildagliptin}

Vildagliptin (Galvus ${ }^{\circledR}$; Novartis AG, Basel, Switzerland) is approved in Europe and in several other countries worldwide for the treatment of type 2 diabetes; however, the FDA has requested additional cardiovascular safety data in order for vildagliptin to gain approval in the US. In June 2008, Novartis indicated that resubmission of a New Drug Application was not planned in order to meet FDA requirements. ${ }^{121}$ 
Despite the fact that vildagliptin will probably not be marketed in the US, recently published clinical trial results indicate that vildagliptin is well tolerated and effectively reduces PPG levels as add-on therapy to metformin (Table 2), ${ }^{122}$ a sulfonylurea (Table 3), ${ }^{123,124}$ or insulin with or without metformin. ${ }^{125}$

\section{Alogliptin}

Alogliptin is a potent and highly selective DPP-4 inhibitor currently being developed by Takeda Pharmaceutical Company Ltd (Osaka, Japan). Takeda submitted a New Drug Application for alogliptin to the FDA in January 2008; however, in June 2009, the FDA requested additional cardiovascular safety data for alogliptin. A clinical cardiovascular outcomes trial of alogliptin is currently recruiting patients (ClinicalTrials.gov identifier NCT00968708). ${ }^{103}$

Compared with sitagliptin, saxagliptin, and vildagliptin, alogliptin has higher selectivity for DPP-4 versus the dipeptidases DPP-8 and DPP-9. This is notable because inhibition of DPP-8 and DPP-9 has been shown to decrease human T-cell activation in vitro and cause multiple organ toxicity in dogs and rats. ${ }^{103}$

In a randomized, placebo-controlled study, significant decreases were observed in mean 4-hour PPG levels over 14 days of treatment with three different doses of once-daily alogliptin compared with placebo (Table 1). Alogliptin was well tolerated; the most commonly reported adverse events were headache, dizziness, and constipation. ${ }^{126}$ In a separate 12-week, randomized, double-blind, placebo-controlled, and active-controlled study of once-daily alogliptin $6.25 \mathrm{mg}$, $12.5 \mathrm{mg}, 25 \mathrm{mg}$, or $50 \mathrm{mg}$, significantly larger decreases in PPG (based on the area under the concentration-time curve from 0 to 2 hours $\left[\mathrm{AUC}_{0-2 \mathrm{~h}}\right]$ ) were observed from baseline to week 12 with all four doses of alogliptin compared with placebo (Table 1). ${ }^{127}$

\section{Dutogliptin}

Dutogliptin is a potent and selective DPP-4 inhibitor with high solubility in water and low cell permeability. Dutogliptin does not bind extensively with plasma proteins. Maximum absorption of dutogliptin occurs within 3-4 hours of dosing, and dutogliptin has a half-life of 10-13 hours. In a randomized, placebo-controlled study, reductions in 2-hour PPG were significantly greater with once-daily dutogliptin than with placebo (Table 1). Dutogliptin was weight-neutral, with a safety profile similar to that of placebo. Across all treatment groups, the most commonly reported adverse events in this study were urinary tract infection (4.3\%), diarrhea
(3.6\%), upper respiratory tract infection (3.6\%), and headache $(3.3 \%) .{ }^{128}$

\section{Comparison of DPP-4 inhibitors and GLP-I receptor agonists}

The DPP-4 inhibitor and GLP-1 receptor agonist classes differ in their food and digestive effects and other clinical aspects, including the extent to which they reduce $\mathrm{HbA}_{1 \mathrm{c}}$, PPG, and body weight (Figure 3). ${ }^{129}$ GLP-1 agonists have shown a greater effect in lowering $\mathrm{HbA}_{1 \mathrm{c}}(-0.4 \%$ to $-1.9 \%)$ compared with DPP-4 inhibitors $\left(-0.4 \%\right.$ to $\left.-0.9 \%{ }^{65,129}\right)$. The clinically relevant impact of such differences on the relative PPG-lowering effects of DPP-4 inhibitors versus GLP-1 receptor agonists has not been extensively addressed. A double-blind, randomized, double-dummy, crossover study ${ }^{130}$ compared the effects of the GLP-1 analog exenatide (5 $\mu \mathrm{g}$ twice daily during week $1,10 \mu \mathrm{g}$ twice daily during week 2) versus the DPP-4 inhibitor sitagliptin (100 mg every morning for 2 weeks) on 2-hour PPG, insulin and glucagon secretion, gastric emptying, and caloric intake in patients with type 2 diabetes $(n=61,28$ male/33 female; mean age $54 \pm 9$ years). Although this study was limited by a 2 -week duration of exposure to each medication, the results showed that the GLP-1 analog reduced 2-hour PPG concentration significantly more than the DPP-4 inhibitor (2-hour PPG concentration at week $2,133 \pm 6 \mathrm{mg} / \mathrm{dL}$ versus $208 \pm 6 \mathrm{mg} / \mathrm{dL}$; $P<0.0001)$. Acute $\beta$-cell function, assessed using the insulinogenic index and insulin secretion rate, improved significantly more following treatment with the GLP-1 analog compared with the DPP-4 inhibitor. In addition, treatment with the GLP-1 receptor agonist was associated with significantly greater reductions in postprandial glucagon secretion, postprandial triglycerides, and caloric intake compared with the DPP-4 inhibitor. Gastric emptying was also delayed to a greater extent with the GLP-1 receptor agonist compared with the DPP-4 inhibitor. ${ }^{130}$

Modest improvements in cardiovascular risk factors such as blood pressure and lipid levels have been reported in patients treated with either DPP-4 inhibitors or GLP-1 receptor agonists. ${ }^{131}$ Recently published pooled analyses of randomized controlled trials in patients with type 2 diabetes mellitus have confirmed a cardioprotective effect for two GLP-1 agonists, ie, exenatide $10 \mu \mathrm{g}$ twice daily ${ }^{132}$ and exenatide once weekly. ${ }^{133}$ In both analyses, treatment with either agent resulted in improved blood pressure and lipid profiles, regardless of baseline age, sex, race, duration of diabetes, or body mass index. Meta-analyses of clinical trial data for the DPP-4 inhibitors saxagliptin and linagliptin 


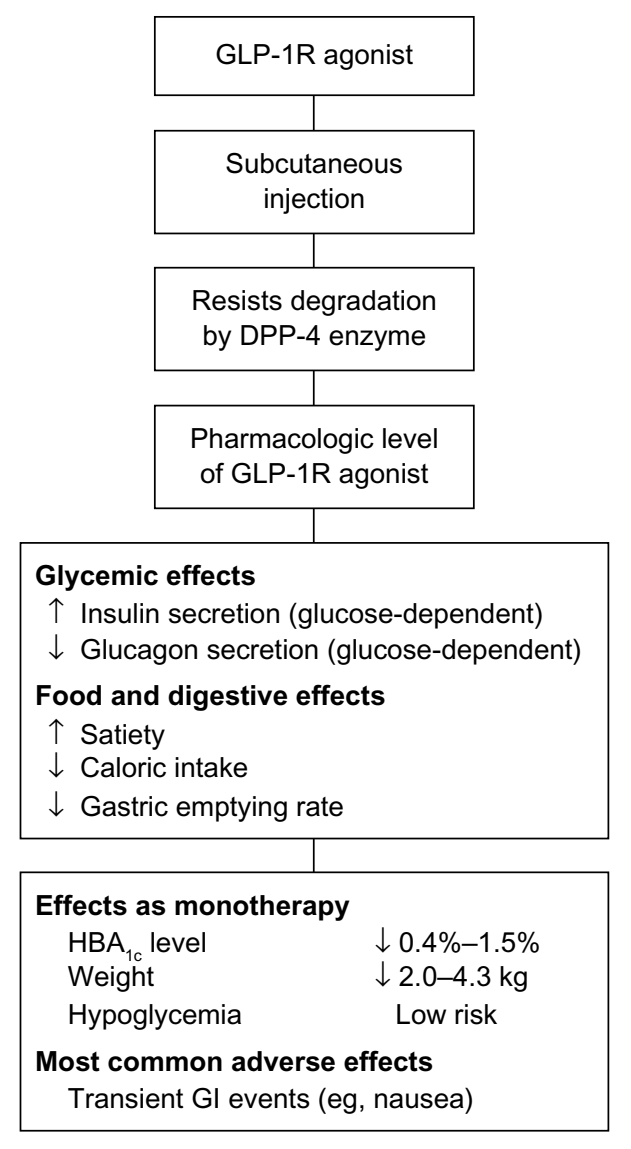

Figure 3 Comparison of GLP-I agonists and DPP-4 inhibitors.

suggest that these drugs are also associated with a decreased cardiovascular risk. ${ }^{134}$ Cardiovascular outcomes trials are needed to confirm whether treatment with DPP-4 inhibitors or GLP-1 receptor agonists will result in long-term reductions in cardiovascular risk and improved patient outcomes. In addition, to satisfy criteria outlined in the December 2008 "Guidance for Industry: Diabetes Mellitus - Evaluating Cardiovascular Risk in New Antidiabetic Therapies to Treat Type 2 Diabetes," the FDA has requested additional cardiovascular safety data as part of the clinical development program for any new type 2 antidiabetic therapy. ${ }^{135}$

Acute pancreatitis has been reported in patients treated with exenatide, ${ }^{136}$ liraglutide, ${ }^{74}$ and sitagliptin, ${ }^{137}$ raising the concern that there may be a mechanism-based association between pancreatitis and incretin therapies. In a retrospective analysis of the FDA's voluntary adverse event reporting database, pancreatitis was found to be reported over six-fold more frequently for either sitagliptin or exenatide therapy compared with four other diabetes therapies (rosiglitazone, nateglinide, repaglinide, and glipizide). ${ }^{138} \mathrm{~A}$ broader retrospective analysis of PubMed articles performed by Drucker et al concludes that preclinical studies do not support an

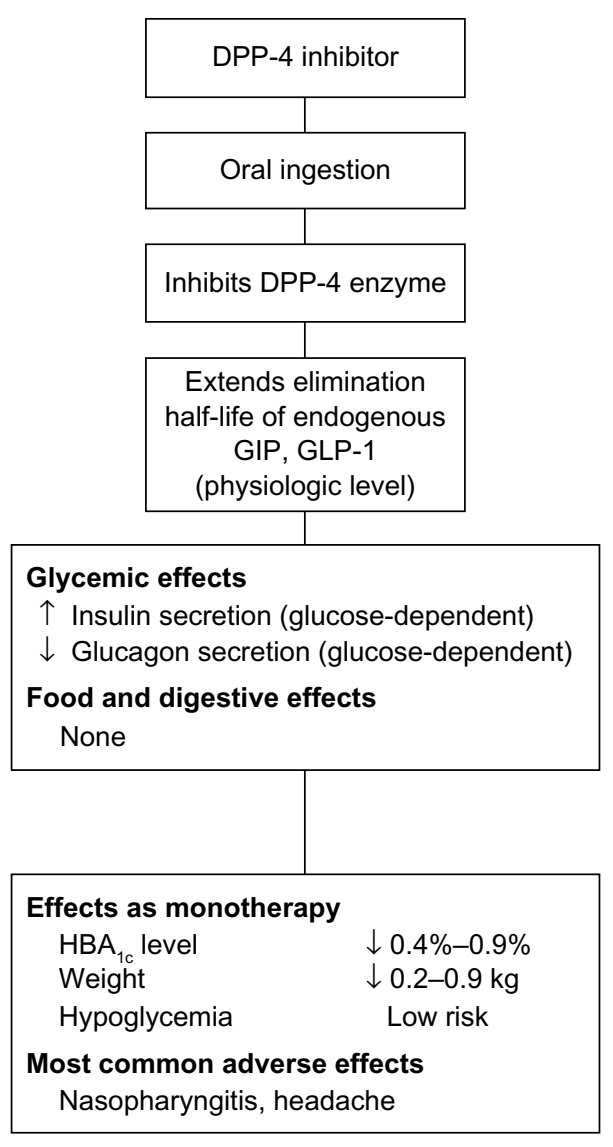

increase in the rate or severity of pancreatitis with exenatide, liraglutide, or sitagliptin treatment and that, overall, retrospective case studies do not link incretin therapies to pancreatitis. ${ }^{139}$ In two retrospective analyses of different health insurance claims databases, the risks of pancreatitis for patients who initiated exenatide or sitagliptin were found to be comparable with those for patients who initiated either metformin or glyburide ${ }^{140}$ and for patients who initiated either a sulfonylurea, biguanide, or thiazolidinedione. ${ }^{141}$ Longer-term, prospective, controlled trials are needed to assess whether a clear association exists between pancreatitis and these incretin therapies. ${ }^{77,142}$ Warnings of the high incidences of acute pancreatitis are included in the most current prescribing information for exenatide twice daily, ${ }^{53}$ exenatide once weekly, ${ }^{52}$ sitagliptin, ${ }^{105}$ and liraglutide, ${ }^{54}$ discontinuation of treatment is recommended if pancreatitis is suspected. Prescribing information for exenatide twice daily ${ }^{53}$ and exenatide once weekly ${ }^{52}$ states that other antidiabetic therapies should be considered in patients with a history of pancreatitis.

The risk of thyroid cancer is another safety concern that has been raised with incretin therapies. In preclinical studies of liraglutide, an increase in the formation of thyroid tumors 
was observed in animal models. ${ }^{77}$ A retrospective analysis of the FDA's adverse event reporting database examined the frequency of reported adverse events of thyroid cancer with two other incretin therapies, exenatide and sitagliptin, compared with rosiglitazone. ${ }^{138}$ Thyroid cancer was reported significantly more often in the exenatide group compared with the rosiglitazone group (odds ratio 4.73; $P=4 \times 10^{-3}$ ) but not in the sitagliptin group (odds ratio 1.48; $P=0.65$ ). As with the risk of pancreatitis, further studies assessing the risk of thyroid cancer and its association with incretin therapies are warranted.

\section{Conclusion}

Current treatment guidelines for type 2 diabetes mellitus emphasize the importance of controlling postprandial hyperglycemia to optimize glycemic control, ${ }^{50,51}$ which may result in a lower risk of cardiovascular morbidity and mortality. GLP-1 receptor agonists and DPP-4 inhibitors both reduce postprandial hyperglycemia and may be particularly beneficial for patients early in the progression of diabetes. Results of recent clinical studies suggest that GLP-1 receptor agonists may provide greater benefit than DPP-4 inhibitors in this regard. Both GLP-1 receptor agonists and DPP-4 inhibitors could become a valuable alternative to rapid-acting insulins, by helping to optimize glycemic control in patients unable to achieve $\mathrm{HbA}_{1 \mathrm{c}}$ goals with basal insulin, with the added benefits of weight loss and a low risk of hypoglycemia.

\section{Disclosure}

The author declares no research funding by pharmaceutical companies, but serves on advisory boards or speaks for sanofi-aventis US LLC, Boehringer Ingelheim $\mathrm{GmbH}$, Eli Lilly and Company, Bristol-Myers Squibb Company, Johnson \& Johnson, and Merck and Co, Inc. Editorial support for the writing of this paper was provided by Nancy Bella of MedErgy, and was funded by sanofi-aventis US LLC. The author was not compensated and retained full editorial control over the content of the manuscript.

\section{References}

1. Gerich JE. The genetic basis of type 2 diabetes mellitus: impaired insulin secretion versus impaired insulin sensitivity. Endocr Rev. 1998;19(4):491-503.

2. Kahn SE. The relative contributions of insulin resistance and beta-cell dysfunction to the pathophysiology of type 2 diabetes. Diabetologia. 2003;46(1):3-19.

3. Stumvoll M, Goldstein BJ, van Haeften TW. Type 2 diabetes: pathogenesis and treatment. Lancet. 2008;371(9631):2153-2156.

4. Gerich JE. Clinical significance, pathogenesis, and management of postprandial hyperglycemia. Arch Intern Med. 2003;163(11):1306-1316.
5. Peter R, Okoseime OE, Rees A, Owens DR. Postprandial glucose - a potential therapeutic target to reduce cardiovascular mortality. Curr Vasc Pharmacol. 2009;7(1):68-74.

6. Monnier L, Colette C, Dunseath GJ, Owens DR. The loss of postprandial glycemic control precedes stepwise deterioration of fasting with worsening diabetes. Diabetes Care. 2007;30(2):263-269.

7. Tibaldi J. Importance of postprandial glucose levels as a target for glycemic control in type 2 diabetes. South Med J. 2009;102(1):60-66.

8. American Diabetes Association. Standards of medical care in diabetes - 2011. Diabetes Care. 2011;34 Suppl 1:S11-S61.

9. Woerle HJ, Neumann C, Zschau S, et al. Impact of fasting and postprandial glycemia on overall glycemic control in type 2 diabetes. Importance of postprandial glycemia to achieve target $\mathrm{HbA}_{1 \mathrm{c}}$ levels. Diabetes Res Clin Pract. 2007;77(2):280-285.

10. International Diabetes Federation. IDF guideline for management of postmeal glucose. Available from: http://www.idf.org/webdata/docs/ Guideline_PMG_final.pdf. Accessed October 26, 2012.

11. Coutinho M, Gerstein HC, Wang Y, Yusuf S. The relationship between glucose and incident cardiovascular events. A metaregression analysis of published data from 20 studies of 95,783 individuals followed for 12.4 years. Diabetes Care. 1999;22(2):233-240.

12. Lin HJ, Lee BC, Ho YL, et al. Postprandial glucose improves the risk prediction of cardiovascular death beyond the metabolic syndrome in the nondiabetic population. Diabetes Care. 2009;32(9):1721-1726.

13. Gallwitz B. Implications of postprandial glucose and weight control in people with type 2 diabetes: understanding and implementing the International Diabetes Federation guidelines. Diabetes Care. 2009; 32 Suppl 2:S322-S325.

14. Ceriello A, Bortolotti N, Motz E, et al. Meal-generated oxidative stress in type 2 diabetic patients. Diabetes Care. 1998;21(9):1529-1533.

15. Ceriello A, Bortolotti N, Motz E, et al. Meal-induced oxidative stress and low-density lipoprotein oxidation in diabetes: the possible role of hyperglycemia. Metabolism. 1999;48(12):1503-1508.

16. Ceriello A, Taboga C, Tonutti L, et al. Evidence for an independent and cumulative effect of postprandial hypertriglyceridemia and hyperglycemia on endothelial dysfunction and oxidative stress generation: effects of short- and long-term simvastatin treatment. Circulation. 2002; 106(10):1211-1218.

17. Inzucchi SE, Bergenstal RM, Buse JB, et al. Management of hyperglycemia in type 2 diabetes: a patient-centered approach. Position statement of the American Diabetes Association (ADA) and the European Association for the Study of Diabetes (EASD). Diabetes Care. 2012;35(6):1364-1379.

18. International Diabetes Federation. IDF guidelines for management of postmeal glucose in patients with diabetes. Available from: http:// www.idf.org/sites/default/files/postmeal\%20glucose\%20guidelines. pdf. Accessed June 6, 2013.

19. Rizzo M, Rizvi AA, Spinas GA, Rini GB, Berneis K. Glucose lowering and anti-atherogenic effects of incretin-based therapies: GLP-1 analogues and DPP-4-inhibitors. Expert Opin Investig Drugs. 2009;18(10): $1495-1503$.

20. Meyer C, Woerle HJ, Dostou JM, Welle SL, Gerich JE. Abnormal renal, hepatic, and muscle glucose metabolism following glucose ingestion in type 2 diabetes. Am J Physiol Endocrinol Metab. 2004;287(6):E1049-E1056.

21. Mitrakou A, Kelley D, Mokan M, et al. Role of reduced suppression of glucose production and diminished early insulin release in impaired glucose tolerance. $N$ Engl J Med. 1992;326(1):22-29.

22. Woerle HJ, Szoke E, Meyer C, et al. Mechanisms for abnormal postprandial glucose metabolism in type 2 diabetes. Am JPhysiol Endocrinol Metab. 2006;290(1):E67-E77.

23. Gerich JE. Postprandial hyperglycemia and cardiovascular disease. Endocr Pract. 2006;12 Suppl 1:47-51.

24. Monnier L, Lapinski H, Colette C. Contributions of fasting and postprandial plasma glucose increments to the overall diurnal hyperglycemia of type 2 diabetic patients: variations with increasing levels of $\mathrm{HbA}_{1 \mathrm{c}}$. Diabetes Care. 2003;26(3):881-885. 
25. Riddle M, Umpierrez G, DiGenio A, Zhou R, Rosenstock J. Contributions of basal and postprandial hyperglycemia over a wide range of $\mathrm{A}_{1 \mathrm{c}}$ levels before and after treatment intensification in type 2 diabetes. Diabetes Care. 2011;34(12):2508-2514.

26. van Haeften TW, Pimenta W, Mitrakou A, et al. Relative contributions of beta-cell function and tissue insulin sensitivity to fasting and postglucose-load glycemia. Metabolism. 2000;49(10):1318-1325.

27. Ceriello A. 25 years of progress in type 2 diabetes. Medicographia. 2011;33:29-34.

28. Ceriello A. Does postprandial blood glucose matter and why? Endocrinol Nutr. 2009;56 Suppl 4:8-11.

29. Node K, Inoue T. Postprandial hyperglycemia as an etiological factor in vascular failure. Cardiovasc Diabetol. 2009;8:23.

30. Standl E, Schnell O, Ceriello A. Postprandial hyperglycemia and glycemic variability: should we care? Diabetes Care. 2011;34 Suppl 2: S120-S127.

31. Defronzo RA. Insulin resistance, lipotoxicity, type 2 diabetes and atherosclerosis: the missing links. The Claude Bernard Lecture 2009. Diabetologia. 2010;53(7):1270-1287.

32. Ceriello A, Cavarape A, Martinelli L, et al. The post-prandial state in type 2 diabetes and endothelial dysfunction: effects of insulin aspart. Diabet Med. 2004;21(2):171-175.

33. Esposito K, Giugliano D, Nappo F, Marfella R; for the Campanian Postprandial Hyperglycemia Study Group. Regression of carotid atherosclerosis by control of postprandial hyperglycemia in type 2 diabetes mellitus. Circulation. 2004;110(2):214-219.

34. Holman RR, Haffner SM, McMurray JJ, et al. Effect of nateglinide on the incidence of diabetes and cardiovascular events. $N$ Engl J Med. 2010;362(16):1463-1476.

35. Gribble FM, Manley SE, Levy JC. Randomized dose ranging study of the reduction of fasting and postprandial glucose in type 2 diabetes by nateglinide (A-4166). Diabetes Care. 2001;24(7):1221-1225.

36. Raz I, Wilson PW, Strojek K, et al. Effects of prandial versus fasting glycemia on cardiovascular outcomes in type 2 diabetes: the HEART2D trial. Diabetes Care. 2009;32(3):381-386.

37. Ceriello A. Postprandial hyperglycemia and cardiovascular disease: is the HEART2D study the answer? Diabetes Care. 2009;32(3): 521-522.

38. Cohen A, Horton ES. Progress in the treatment of type 2 diabetes: new pharmacologic approaches to improve glycemic control. Curr Med Res Opin. 2007;23(4):905-917.

39. Garg SK. The role of basal insulin and glucagon-like peptide-1 agonists in the therapeutic management of type 2 diabetes - a comprehensive review. Diabetes Technol Ther. 2010;12(1):11-24.

40. Drucker DJ, Nauck MA. The incretin system: glucagon-like peptide-1 receptor agonists and dipeptidyl peptidase-4 inhibitors in type 2 diabetes. Lancet. 2006;368(9548):1696-1705.

41. Aryangat AV, Gerich JE. Type 2 diabetes: postprandial hyperglycemia and increased cardiovascular risk. Vasc Health Risk Manag. 2010;6: $145-155$.

42. Nicolaus M, Brodl J, Linke R, Woerle HJ, Goke B, Schirra J. Endogenous GLP-1 regulates postprandial glycemia in humans: relative contributions of insulin, glucagon, and gastric emptying. J Clin Endocrinol Metab. 2011;96(1):229-236.

43. Neumiller JJ. Differential chemistry (structure), mechanism of action, and pharmacology of GLP-1 receptor agonists and DPP-4 inhibitors. J Am Pharm Assoc (2003). 2009;49 Suppl 1:S16-S29.

44. Vollmer K, Gardiwal H, Menge BA, et al. Hyperglycemia acutely lowers the postprandial excursions of glucagon-like Peptide- 1 and gastric inhibitory polypeptide in humans. J Clin Endocrinol Metab. 2009;94(4):1379-1385.

45. Drucker DJ. The biology of incretin hormones. Cell Metab. 2006;3(3): 153-165.

46. Farilla L, Bulotta A, Hirshberg B, et al. Glucagon-like peptide 1 inhibits cell apoptosis and improves glucose responsiveness of freshly isolated human islets. Endocrinology. 2003;144(12): 5149-5158.
47. Perfetti R, Hui H. The role of GLP-1 in the life and death of pancreatic beta cells. Horm Metab Res. 2004;36(11-12):804-810.

48. Campbell RK, Cobble ME, Reid TS, Shomali ME. Distinguishing among incretin-based therapies. Pathophysiology of type 2 diabetes mellitus: potential role of incretin-based therapies. J Fam Pract. 2010;59(9 Suppl 1):S5-S9.

49. Monami M, Marchionni N, Mannucci E. Glucagon-like peptide-1 receptor agonists in type 2 diabetes: a meta-analysis of randomized clinical trials. Eur J Endocrinol. 2009;160(6):909-917.

50. Nathan DM, Buse JB, Davidson MB, et al. Medical management of hyperglycemia in type 2 diabetes: a consensus algorithm for the initiation and adjustment of therapy: a consensus statement of the American Diabetes Association and the European Association for the Study of Diabetes. Diabetes Care. 2009;32(1):193-203.

51. McCulloch DK. Management of persistent hyperglycemia in type 2 diabetes mellitus. Available from: http://www.uptodate.com/contents/ management-of-persistent-hyperglycemia-in-type-2-diabetesmellitus?source=search_result\&search $=$ management + of + persistent + hy perglycemia + in + type $+2+$ diabetes\&selectedTitle $=1 \% 7 \mathrm{E} 150$. Accessed October 26, 2012.

52. Byetta ${ }^{\circledR}$ (exenatide) injection [package insert]. San Diego, CA: Amylin Pharmaceuticals Inc; 2010.

53. BYDUREONTM (exenatide extended-release for injectable suspension) [package insert]. San Diego, CA: Amylin Pharmaceuticals Inc; 2012.

54. Victoza $^{\circledR}$ (liraglutide [rDNA origin] injection) [package insert]. Bagsvaerd, Denmark: Novo Nordisk A/S; 2012.

55. Hollander PA, Kushner P. Type 2 diabetes comorbidities and treatment challenges: rationale for DPP-4 inhibitors. Postgrad Med. 2010;122(3): $71-80$.

56. Schwartz EA, Koska J, Mullin MP, Syoufi I, Schwenke DC, Reaven PD. Exenatide suppresses postprandial elevations in lipids and lipoproteins in individuals with impaired glucose tolerance and recent onset type 2 diabetes mellitus. Atherosclerosis. 2010;212(1): 217-222.

57. Cervera A, Wajcberg E, Sriwijitkamol A, et al. Mechanism of action of exenatide to reduce postprandial hyperglycemia in type 2 diabetes. Am J Physiol Endocrinol Metab. 2008;294(5):E846-E852.

58. Apovian CM, Bergenstal RM, Cuddihy RM, et al. Effects of exenatide combined with lifestyle modification in patients with type 2 diabetes. Am J Med. 2010;123(5):468. e9-e17.

59. Moretto TJ, Milton DR, Ridge TD, et al. Efficacy and tolerability of exenatide monotherapy over 24 weeks in antidiabetic drug-naive patients with type 2 diabetes: a randomized, double-blind, placebo-controlled, parallel-group study. Clin Ther. 2008;30(8):1448-1460.

60. Gao Y, Yoon KH, Chuang LM, et al. Efficacy and safety of exenatide in patients of Asian descent with type 2 diabetes inadequately controlled with metformin or metformin and a sulphonylurea. Diabetes Res Clin Pract. 2009;83(1):69-76.

61. Brodows RG, Qu Y, Johns D, Kim D, Holcombe JH. Quantifying the effect of exenatide and insulin glargine on postprandial glucose excursions in patients with type 2 diabetes. Curr Med Res Opin. 2008;24(5): 1395-1397.

62. Bunck MC, Corner A, Eliasson B, et al. One-year treatment with exenatide vs insulin glargine: effects on postprandial glycemia, lipid profiles, and oxidative stress. Atherosclerosis. 2010;212(1): 223-229.

63. Schwartz SL, Ratner RE, Kim DD, et al. Effect of exenatide on 24-hour blood glucose profile compared with placebo in patients with type 2 diabetes: a randomized, double-blind, two-arm, parallelgroup, placebo-controlled, 2-week study. Clin Ther. 2008;30(5): $858-867$.

64. Buse JB, Bergenstal RM, Glass LC, et al. Use of twice-daily exenatide in basal insulin-treated patients with type 2 diabetes: a randomized, controlled trial. Ann Intern Med. 2011;154(2):103-112.

65. Drucker DJ, Buse JB, Taylor K, et al. Exenatide once weekly versus twice daily for the treatment of type 2 diabetes: a randomised, openlabel, non-inferiority study. Lancet. 2008;372(9645):1240-1250. 
66. Blevins T, Pullman J, Malloy J, et al. DURATION-5: exenatide once weekly resulted in greater improvements in glycemic control compared with exenatide twice daily in patients with type 2 diabetes. J Clin Endocrinol Metab. 2011;96(5):1301-1310.

67. Diamant M, Van GL, Stranks S, et al. Once weekly exenatide compared with insulin glargine titrated to target in patients with type 2 diabetes (DURATION-3): an open-label randomised trial. Lancet. 2010;375(9733):2234-2243.

68. Bergenstal RM, Wysham C, MacConell L, et al. Efficacy and safety of exenatide once weekly versus sitagliptin or pioglitazone as an adjunct to metformin for treatment of type 2 diabetes (DURATION-2): a randomised trial. Lancet. 2010;376(9739):431-439.

69. Taylor K, Gurney K, Han J, Pencek R, Walsh B, Trautmann M. Exenatide once weekly treatment maintained improvements in glycemic control and weight loss over 2 years. BMC Endocr Disord. 2011;11:9.

70. Wysham C, Bergenstal R, Malloy J, et al. DURATION-2: efficacy and safety of switching from maximum daily sitagliptin or pioglitazone to once-weekly exenatide. Diabet Med. 2011;28(6):705-714.

71. Edavalath M, Stephens JW. Liraglutide in the treatment of type 2 diabetes mellitus: clinical utility and patient perspectives. Patient Prefer Adherence. 2010;4:61-68.

72. Flint A, Kapitza C, Hindsberger C, Zdravkovic M. The once-daily human glucagon-like peptide-1 (GLP-1) analog liraglutide improves postprandial glucose levels in type 2 diabetes patients. Adv Ther 2011;28(3):213-226.

73. Seino Y, Rasmussen MF, Zdravkovic M, Kaku K. Dose-dependent improvement in glycemia with once-daily liraglutide without hypoglycemia or weight gain: a double-blind, randomized, controlled trial in Japanese patients with type 2 diabetes. Diabetes Res Clin Pract 2008;81(2):161-168.

74. Garber A, Henry R, Ratner R, et al. Liraglutide versus glimepiride monotherapy for type 2 diabetes (LEAD-3 Mono): a randomised, 52-week, phase III, double-blind, parallel-treatment trial. Lancet. 2009;373(9662):473-481.

75. Kaku K, Rasmussen MF, Clauson P, Seino Y. Improved glycaemic control with minimal hypoglycaemia and no weight change with the once-daily human glucagon-like peptide-1 analogue liraglutide as add-on to sulphonylurea in Japanese patients with type 2 diabetes Diabetes Obes Metab. 2010;12(4):341-347.

76. Buse JB, Rosenstock J, Sesti G, et al. Liraglutide once a day versus exenatide twice a day for type 2 diabetes: a 26-week randomised, parallel-group, multinational, open-label trial (LEAD-6). Lancet. 2009;374(9683):39-47.

77. Drucker DJ, Sherman SI, Gorelick FS, Bergenstal RM, Sherwin RS, Buse JB. Incretin-based therapies for the treatment of type 2 diabetes: evaluation of the risks and benefits. Diabetes Care. 2010;33(2): 428-433.

78. Werner U, Haschke G, Herling AW, Kramer W. Pharmacological profile of lixisenatide: A new GLP-1 receptor agonist for the treatment of type 2 diabetes. Regul Pept. 2010;164(2-3):58-64.

79. Ratner RE, Rosenstock J, Boka G. Dose-dependent effects of the oncedaily GLP-1 receptor agonist lixisenatide in patients with type 2 diabetes inadequately controlled with metformin: a randomized, double-blind, placebo-controlled trial. Diabet Med. 2010;27(9):1024-1032.

80. Riddle MC, Aronson R, Home P, et al. Adding once-daily lixisenatide for type 2 diabetes inadequately controlled by established basal insulin: a 24-week, randomized, placebo-controlled comparison (GetGoal-L). Diabetes Care. 2013;36(9):2489-2496.

81. Pinget M, Goldenberg R, Niemoeller E, Muehlen-Bartmer I, Guo H, Aronson R. Efficacy and safety of lixisenatide once daily versus placebo in type 2 diabetes insufficiently controlled on pioglitazone (Getgoal-P). Diabetes Obes Metab. 2013;15(11):1000-1007.

82. Riddle MC, Forst T, Aronson R, et al. Adding once-daily lixisenatide for type 2 diabetes inadequately controlled with newly initiated and continuously titrated basal insulin glargine: a 24-week, randomized, placebo-controlled study (GetGoal-Duo 1). Diabetes Care. 2013;36(9): 2497-2503.
83. Barnett AH. Lixisenatide: evidence for its potential use in the treatment of type 2 diabetes. Core Evid. 2011;6:67-79.

84. Fonseca VA, Alvarado-Ruiz R, Raccah D, Boka G, Miossec P, Gerich JE. Efficacy and safety of the once-daily GLP-1 receptor agonist lixisenatide in monotherapy: a randomized, double-blind, placebocontrolled trial in patients with type 2 diabetes (GetGoal-Mono). Diabetes Care. 2012;35(6):1225-1231.

85. Seino Y, Min KW, Niemoeller E, Takami A. Randomized, doubleblind, placebo-controlled trial of the once-daily GLP-1 receptor agonist lixisenatide in Asian patients with type 2 diabetes insufficiently controlled on basal insulin with or without a sulfonylurea (GetGoal-L-Asia). Diabetes Obes Metab. 2012;14(10):910-917.

86. Ratner R, Hanefeld M, Shamanna P, et al. Efficacy and safety of lixisenatide once daily versus placebo in patients with T2DM insufficiently controlled on sulfonylurea \pm metformin (GetGoal-S). Diabetologia. 2011;54:S317.

87. Horowitz M, Rayner CK, Jones KL. Mechanisms and clinical efficacy of lixisenatide for the management of type 2 diabetes. Adv Ther. 2013;30(2):81-101.

88. Matthews JE, Stewart MW, De Boever EH, et al. Pharmacodynamics, pharmacokinetics, safety, and tolerability of albiglutide, a long-acting glucagon-like peptide-1 mimetic, in patients with type 2 diabetes. $J$ Clin Endocrinol Metab. 2008;93(12):4810-4817.

89. Rosenstock J, Reusch J, Bush M, Yang F, Stewart M. Potential of albiglutide, a long-acting GLP-1 receptor agonist, in type 2 diabetes: a randomized controlled trial exploring weekly, biweekly, and monthly dosing. Diabetes Care. 2009;32(10):1880-1886.

90. Hassan M, Eskilsson A, Nilsson C, et al. In vivo dynamic distribution of 131I-glucagon-like peptide-1 (7-36) amide in the rat studied by gamma camera. Nucl Med Biol. 1999;26(4):413-420.

91. Kastin AJ, Akerstrom V, Pan W. Interactions of glucagon-like peptide-1 (GLP-1) with the blood-brain barrier. J Mol Neurosci. 2002;18(1-2):7-14.

92. Kastin AJ, Akerstrom V. Entry of exendin-4 into brain is rapid but may be limited at high doses. Int J Obes Relat Metab Disord. 2003;27(3): 313-318.

93. McClean PL, Parthsarathy V, Faivre E, Holscher C. The diabetes drug liraglutide prevents degenerative processes in a mouse model of Alzheimer's disease. J Neurosci. 2011;31(17):6587-6594.

94. Baggio LL, Huang Q, Brown TJ, Drucker DJ. A recombinant human glucagon-like peptide (GLP)-1-albumin protein (albugon) mimics peptidergic activation of GLP-1 receptor-dependent pathways coupled with satiety, gastrointestinal motility, and glucose homeostasis. Diabetes. 2004;53(9):2492-2500.

95. Rosenstock J, Ahren B, Chow FC, et al. Once-weekly GLP-1 receptor agonist albiglutide vs titrated prandial lispro added on to titrated basal insulin glargine in type 2 diabetes (T2D) uncontrolled on glargine plus oral agents: similar glycemic control with weight loss and less hypoglycemia. Diabetes. 2012;61 Suppl 1:A15.

96. Pratley RE, Barnett AH, Feinglos MN, et al. Efficacy and safety of once-weekly (QW) albiglutide vs once-daily (QD) liraglutide in type 2 diabetes (T2D) inadequately controlled on oral agents: HARMONY 7 trial. Diabetes. 2012;61 Suppl 1.

97. Fonseca VL, Ahren B, Chow F, et al. Once weekly GLP-1 receptor agonist albiglutide vs prandial lispro added to basal glargine in type 2 diabetes: similar control with weight loss and less hypoglycemia. Poster presented at the 2012 European Association for the Study of Diabetes (EASD) Meeting, October 1-5, 2012, Berlin, Germany. 2012.

98. Fineman MS, Cirincione BB, Maggs D, Diamant M. GLP-1 based therapies: differential effects on fasting and postprandial glucose. Diabetes Obes Metab. 2012;14(8):675-688.

99. Ahren A, Dimas L, Miossec P, et al. Efficacy and safety of lixisenatide QD morning and evening injections vs placebo in T2DM inadequately controlled on metformin (GetGoal-M). World Diabetes Congress of the International Diabetes Federation, December 4-8, 2011, Dubai, United Arab Emirates, 2011. 
100. Kapitza C, Forst T, Coester HV, Poitiers F, Ruus P, Hincelin-Mery A. Pharmacodynamic characteristics of lixisenatide once daily versus liraglutide once daily in patients with type 2 diabetes insufficiently controlled on metformin. Diabetes Obes Metab. 2013;15(7):642-649.

101. Nauck MA, Kemmeries G, Holst JJ, Meier JJ. Rapid tachyphylaxis of the glucagon-like peptide 1-induced deceleration of gastric emptying in humans. Diabetes. 2011;60(5):1561-1565.

102. Rodbard HW, Jellinger PS, Davidson JA, et al. Statement by an American Association of Clinical Endocrinologists/American College of Endocrinology consensus panel on type 2 diabetes mellitus: an algorithm for glycemic control. Endocr Pract. 2009;15(6):540-559.

103. Ghatak SB, Patel DS, Shanker N, Srivstava A, Deshpande SS, Panchal SJ. Alogliptin: a novel molecule for improving glycemic control in type II diabetes mellitus. Curr Diabetes Rev. 2010;6(6): 410-421.

104. Bock G, Dalla Man C, Micheletto F, et al. The effect of DPP-4 inhibition with sitagliptin on incretin secretion and on fasting and postprandial glucose turnover in subjects with impaired fasting glucose. Clin Endocrinol (Oxf). 2010;73(2):189-196.

105. Januvia ${ }^{\mathrm{TM}}$ (sitagliptin) tablets [package insert]. Whitehouse Station, NJ: Merck and Co Inc; 2012.

106. Onglyza ${ }^{\mathrm{TM}}$ (saxagliptin) tablets [package insert]. Princeton, NJ: Bristol-Myers Squibb Company; 2011.

107. Tradjenta ${ }^{\mathrm{TM}}$ (linagliptin) tablets [package insert]. Ridgefield, CT: Boehringer Ingelheim Pharmaceuticals Inc; 2011.

108. Del Prato S, BarnettAH, Huisman H, Neubacher D, Woerle HJ, Dugi KA. Effect of linagliptin monotherapy on glycaemic control and markers of beta-cell function in patients with inadequately controlled type 2 diabetes: a randomized controlled trial. Diabetes Obes Metab. 2011;13(3):258-267.

109. Rosenstock J, Aguilar-Salinas C, Klein E, Nepal S, List J, Chen R; CV181-011 Study Investigators. Effect of saxagliptin monotherapy in treatment-naive patients with type 2 diabetes. Curr Med Res Opin. 2009;25(10):2401-2411.

110. Nonaka K, Kakikawa T, Sato A, et al. Efficacy and safety of sitagliptin monotherapy in Japanese patients with type 2 diabetes. Diabetes Res Clin Pract. 2008;79(2):291-298.

111. Iwamoto Y, Taniguchi T, Nonaka K, et al. Dose-ranging efficacy of sitagliptin, a dipeptidyl peptidase-4 inhibitor, in Japanese patients with type 2 diabetes mellitus. Endocr J. 2010;57(5):383-394.

112. Taskinen MR, Rosenstock J, Tamminen I, et al. Safety and efficacy of linagliptin as add-on therapy to metformin in patients with type 2 diabetes: a randomized, double-blind, placebo-controlled study. Diabetes Obes Metab. 2011;13(1):65-74.

113. Defronzo RA, Hissa MN, Garber AJ, et al. The efficacy and safety of saxagliptin when added to metformin therapy in patients with inadequately controlled type 2 diabetes with metformin alone. Diabetes Care. 2009;32(9):1649-1655.

114. Stenlof K, Raz I, Neutel J, Ravichandran S, Berglind N, Chen R. Saxagliptin and metformin XR combination therapy provides glycemic control over 24 hours in patients with T2DM inadequately controlled with metformin. Curr Med Res Opin. 2010;26(10):2355-2363.

115. Chacra AR, Tan GH, Ravichandran S, List J, Chen R. Safety and efficacy of saxagliptin in combination with submaximal sulphonylurea versus up-titrated sulphonylurea over 76 weeks. Diab Vasc Dis Res. 2011;8(2):150-159.

116. Chacra AR, Tan GH, Apanovitch A, Ravichandran S, List J, Chen R. Saxagliptin added to a submaximal dose of sulphonylurea improves glycaemic control compared with uptitration of sulphonylurea in patients with type 2 diabetes: a randomised controlled trial. Int J Clin Pract. 2009;63(9):1395-1406.

117. Barnett AH, Charbonnel B, Donovan M, Fleming D, Chen R. Effect of saxagliptin as add-on therapy in patients with poorly controlled type 2 diabetes on insulin alone or insulin combined with metformin. Curr Med Res Opin. 2012;28(4):513-523.
118. Minervini G, Charbonnel B, Barnett AH, Monyak J, Iqbal N. Efficacy and safety of saxagliptin in combination with insulin in patients with long-standing type 2 diabetes. Abstract presented at the American Diabetes Association 72nd Scientific Sessions, June 8-12, 2012, Philadelphia, PA, 2012.

119. Vilsboll T, Rosenstock J, Yki-Jarvinen H, et al. Efficacy and safety of sitagliptin when added to insulin therapy in patients with type 2 diabetes. Diabetes Obes Metab. 2010;12(2):167-177.

120. Yki-Jarvinen H, Duran-Garcia S, Pinnetti S, et al. Efficacy and safety of linagliptin as add-on therapy to basal insulin in patients with type 2 diabetes. Abstract presented at the American Diabetes Association 72nd Scientific Sessions, June 8-12, 2012, Philadelphia, PA, 2012.

121. Viereck C, Boudes P. An analysis of the impact of FDA's guidelines for addressing cardiovascular risk of drugs for type 2 diabetes on clinical development. Contemp Clin Trials. 2011;32(3):324-332.

122. Ahrén B, Foley JE, Ferrannini E, et al. Changes in prandial glucagon levels after a 2-year treatment with vildagliptin or glimepiride in patients with type 2 diabetes inadequately controlled with metformin monotherapy. Diabetes Care. 2010;33(4):730-732.

123. Derosa G, Maffioli P, Ferrari I, et al. Effects of one year treatment of vildagliptin added to pioglitazone or glimepiride in poorly controlled type 2 diabetic patients. Horm Metab Res. 2010;42(9):663-669.

124. Garber AJ, Foley JE, Banerji MA, et al. Effects of vildagliptin on glucose control in patients with type 2 diabetes inadequately controlled with a sulphonylurea. Diabetes Obes Metab. 2008;10(11):1047-1056.

125. Lukashevich V, Kozlovski P, Foley J, Kothny W. Vildagliptin combined with insulin reduces $\mathrm{HbA}_{\mathrm{lc}}$ without increasing risk of hypoglycemia and weight gain in patients with type 2 diabetes mellitus. Abstract presented at the American Diabetes Association 72nd Scientific Sessions, June 8-12, 2012, Philadelphia, PA, 2012.

126. Covington P, Christopher R, Davenport M, et al. Pharmacokinetic, pharmacodynamic, and tolerability profiles of the dipeptidyl peptidase-4 inhibitor alogliptin: a randomized, double-blind, placebocontrolled, multiple-dose study in adult patients with type 2 diabetes. Clin Ther. 2008;30(3):499-512.

127. Seino Y, Fujita T, Hiroi S, Hirayama M, Kaku K. Efficacy and safety of alogliptin in Japanese patients with type 2 diabetes mellitus: a randomized, double-blind, dose-ranging comparison with placebo, followed by a long-term extension study. Curr Med Res Opin. 2011;27(9): 1781-1792.

128. Pattzi HM, Pitale S, Alpizar M, et al. Dutogliptin, a selective DPP4 inhibitor, improves glycaemic control in patients with type 2 diabetes: a 12-week, double-blind, randomized, placebo-controlled, multicentre trial. Diabetes Obes Metab. 2010;12(4):348-355.

129. Morales J. The pharmacologic basis for clinical differences among GLP-1 receptor agonists and DPP-4 inhibitors. Postgrad Med. 2011;123(6):189-201.

130. Defronzo RA, Okerson T, Viswanathan P, Guan X, Holcombe JH, MacConell L. Effects of exenatide versus sitagliptin on postprandial glucose, insulin and glucagon secretion, gastric emptying, and caloric intake: a randomized, cross-over study. Curr Med Res Opin. 2008;24(10):2943-2952.

131. Sulistio M, Carothers C, Mangat M, Lujan M, Oliveros R, Chilton R. GLP-1 agonist-based therapies: an emerging new class of antidiabetic drug with potential cardioprotective effects. Curr Atheroscler Rep. 2009;11(2):93-99.

132. Pencek R, Blickensderfer A, Li Y, Brunell S, Anderson P. Exenatide twice daily: analysis of effectiveness and safety data stratified by age, sex, race, duration of diabetes, and body mass index. Postgrad Med. 2012;124(4):21-32.

133. Pencek R, Brunell S, Li Y, Hoogwerf BJ, Malone J. Exenatide once weekly for the treatment of type 2 diabetes mellitus: clinical results in subgroups of patients using different concomitant medications. Postgrad Med. 2012;124(4):33-40.

134. Green JB. The dipeptidyl peptidase- 4 inhibitors in type 2 diabetes mellitus: cardiovascular safety. Postgrad Med. 2012;124(4):54-61. 
135. US Department of Health and Human Services Food and Drug Administration Center for Drug Evaluation and Research (CDER). Guidance for industry: diabetes mellitus - evaluating cardiovascular risk in new antidiabetic therapies to treat type 2 diabetes. Aailable from: http://www.fda.gov/downloads/Drugs/GuidanceCompliance RegulatoryInformation/\%20Guidances/UCM071627.pdf. Accessed October 26, 2012.

136. Ahmad SR, Swann J. Exenatide and rare adverse events. $N$ Engl J Med. 2008;358(18):1970-1971.

137. Engel SS, Williams-Herman DE, Golm GT, et al. Sitagliptin: review of preclinical and clinical data regarding incidence of pancreatitis. Int J Clin Pract. 2010;64(7):984-990.

138. Elashoff M, Matveyenko AV, Gier B, Elashoff R, Butler PC. Pancreatitis, pancreatic, and thyroid cancer with glucagon-like peptide1-based therapies. Gastroenterology. 2011;141(1):150-156.

139. Drucker DJ, Sherman SI, Bergenstal RM, Buse JB. The safety of incretin-based therapies - review of the scientific evidence. $J$ Clin Endocrinol Metab. 2011;96(7):2027-2031.

140. Dore DD, Seeger JD, Arnold CK. Use of a claims-based active drug safety surveillance system to assess the risk of acute pancreatitis with exenatide or sitagliptin compared to metformin or glyburide. Curr Med Res Opin. 2009;25(4):1019-1027.

141. Garg R, Chen W, Pendergrass M. Acute pancreatitis in type 2 diabetes treated with exenatide or sitagliptin: a retrospective observational pharmacy claims analysis. Diabetes Care. 2010;33(11):2349-2354.

142. Butler PC, Dry S, Elashoff R. GLP-1-based therapy for diabetes: what you do not know can hurt you. Diabetes Care. 2010;33(2):453-455.
143. Barzilai N, Guo H, Mahoney EM, et al. Efficacy and tolerability of sitagliptin monotherapy in elderly patients with type 2 diabetes: a randomized, double-blind, placebo-controlled trial. Curr Med Res Opin. 2011;27(5):1049-1058.

144. Pan CY, Yang W, Tou C, Gause-Nilsson I, Zhao J. Efficacy and safety of saxagliptin in drug-naive Asian patients with type 2 diabetes mellitus: a randomized controlled trial. Diabetes Metab Res Rev. 2012;28(3):268-275.

145. Forst T, Uhlig-Laske B, Ring A, Ritzhaupt A, Graefe-Mody U, Dugi KA. The oral DPP-4 inhibitor linagliptin significantly lowers $\mathrm{HbA}_{1 \mathrm{c}}$ after 4 weeks of treatment in patients with type 2 diabetes mellitus. Diabetes Obes Metab. 2011;13(6):542-550.

146. Seck T, Nauck M, Sheng D, et al. Safety and efficacy of treatment with sitagliptin or glipizide in patients with type 2 diabetes inadequately controlled on metformin: a 2-year study. Int J Clin Pract. 2010;64(5) 562-576.

147. Stenlof K, Raz I, Neutel J, Ravichandran S, Berglind N, Chen R. Saxagliptin and metformin XR combination therapy provides glycemic control over 24 hours in patients with T2DM inadequately controlled with metformin. Curr Med Res Opin. 2010;26(10):2355-2363.

148. Fonseca V, Zhu T, Karyekar C, Hirshberg B. Adding saxagliptin to extended-release metformin vs uptitrating metformin dosage. Diabetes Obes Metab. 2012;14(4):365-371.

149. Ferrannini E, Fonseca V, Zinman B, et al. Fifty-two-week efficacy and safety of vildagliptin vs glimepiride in patients with type 2 diabetes mellitus inadequately controlled on metformin monotherapy. Diabetes Obes Metab. 2009;11(2):157-166.
International Journal of General Medicine

\section{Publish your work in this journal}

The International Journal of General Medicine is an international, peer-reviewed open-access journal that focuses on general and internal medicine, pathogenesis, epidemiology, diagnosis, monitoring and treatment protocols. The journal is characterized by the rapid reporting of reviews, original research and clinical studies across all disease areas.

\section{Dovepress}

A key focus is the elucidation of disease processes and management protocols resulting in improved outcomes for the patient.The manuscript management system is completely online and includes a very quick and fair peer-review system. Visit http://www.dovepress.com/ testimonials.php to read real quotes from published authors. 